\title{
Regional and local patterns in depth to water table, hydrochemistry and peat properties of bogs and their laggs in coastal British Columbia
}

\author{
S. A. Howie ${ }^{1,2}$ and H. J. van Meerveld ${ }^{3}$ \\ ${ }^{1}$ Simon Fraser University, Geography Department, 8888 University Drive, Burnaby, BC V5A 1S6, Canada \\ ${ }^{2}$ The Corporation of Delta, Engineering Department, 4500 Clarence Taylor Crescent, Delta, BC V4K 3E2, Canada \\ ${ }^{3}$ VU University Amsterdam, Critical Zone Hydrology Group, De Boelelaan 1085, 1081 HV Amsterdam, the Netherlands
}

Correspondence to: S. A. Howie (sarah_howie@sfu.ca)

Received: 12 January 2013 - Published in Hydrol. Earth Syst. Sci. Discuss.: 12 March 2013

Revised: 21 July 2013 - Accepted: 22 July 2013 - Published: 5 September 2013

\begin{abstract}
In restoration planning for damaged raised bogs, the lagg at the bog margin is often not given considerable weight and is sometimes disregarded entirely. However, the lagg is critical for the proper functioning of the bog, as it supports the water mound in the bog. In order to include the lagg in a restoration plan for a raised bog, it is necessary to understand the hydrological characteristics and functions of this rarely studied transition zone. We studied 13 coastal British Columbia (BC) bogs and identified two different gradients in depth to water table, hydrochemistry and peat properties: (1) a local bog expanse-bog margin gradient, and (2) a regional gradient related to climate and proximity to the ocean. Depth to water table generally increased across the transition from bog expanse to bog margin. In the bog expanse, $\mathrm{pH}$ was above 4.2 in the Pacific Oceanic wetland region (cooler and wetter climate) and below 4.3 in the Pacific Temperate wetland region (warmer and drier climate). Both $\mathrm{pH}$ and $\mathrm{pH}$-corrected electrical conductivity increased significantly across the transition from bog expanse to bog margin, though not in all cases. $\mathrm{Na}^{+}$and $\mathrm{Mg}^{2+}$ concentrations were generally highest in exposed, oceanic bogs and lower in inland bogs. Ash content in peat samples increased across the bog expanse-bog margin transition, and appears to be a useful abiotic indicator of the location of the bog margin. The observed variation in the hydrological and hydrochemical gradients across the bog expanse-bog margin transition highlights both local and regional diversity of bogs and their associated laggs.
\end{abstract}

\section{Introduction}

One of the most extensively studied topics in peatland research is the poor-rich gradient (i.e. the continuum from ombrotrophic raised bogs to minerotrophic rich fens) in both vegetation and water chemistry (e.g. Sjörs, 1950; Moore and Bellamy, 1974; Glaser, 1992; Tahvanainen et al., 2002). Only a few studies have looked at the related hydrochemical transition from the bog expanse to the bog margin (e.g. Sjörs, 1950; Bubier, 1991; Blackwell, 1992; Mitchell et al., 2008; Richardson et al., 2010). This research often specifically concerns the mineral soil water limit, which is the boundary between water from only atmospheric sources and mineral soil water. This boundary is often (but not always) associated with a distinct change in vegetative communities (Ivanov, 1981; Damman, 1986). The variable topography around the margins of raised bogs, however, results in a diverse set of transition forms, even around a single bog. Where a topographic depression forms at the margin of a bog, a welldefined ecotone may develop due to a higher groundwater table and mixing of bog water with non-bog water. In other cases, the topographic transition outward from the bog may be less distinct, and vegetation may change from open bog to forest without a clear ecotone (Howie and Tromp-van Meerveld, 2011).

The majority of bog studies focus on the central bog expanse; very few studies have included a detailed investigation of the lagg (i.e. the vegetative transition zone at the bog margin where water from the bog and the surrounding mineral soil mix), with the exception of literature related to the 
development and structure of raised bogs (e.g. Ivanov, 1981; Damman and French, 1987). The lagg is an integral part of the hydrological system of a raised bog because it helps support the water mound of the bog and buffers the bog from surrounding minerotrophic water (Schouten, 2002; Damman, 1986). However, marginal zones, such as the lagg, tend to be disturbed first for agriculture or other development, and are frequently disturbed even for bogs that are in a (near) natural condition in their central parts. A greater understanding of this transition zone, however, is critical for understanding the hydrological and ecological functioning of raised bogs, and for the delineation of conservation boundaries and development of ecological restoration plans (Howie and Tromp-van Meerveld, 2011). Delineation of the boundary of a potential lagg conservation zone requires an understanding of the geomorphology, hydrology, hydrochemistry, peat properties and vegetation at the bog margin. Knowledge about local lagg characteristics and their variability also aids in the development of a list of measurable lagg indicators (e.g. pH, $\mathrm{Ca}^{2+}$ concentration, ash content of the peat) to be used in restoration strategies or as restoration goals.

Depth to water table varies across the bog expanse-bog margin transition and is closely linked to plant community composition. The characteristic raised bog vegetation patterns from the bog to the margin consist of (1) central open heath, where a consistently high water table supports Sphagnum and ericaceous shrubs, (2) marginal rand forest, where a lower water table supports tall shrubs and trees, and (3) lagg fen/swamp, where a highly fluctuating water table and mineral soil support fen or swamp species (Damman, 1986). Hydrochemical characteristics also vary across the transition from the bog to the margin, and have a strong influence on vegetative composition (Bridgham et al., 1996; Wassen and Joosten, 1996). For example, Glaser et al. (1990) found increasing species richness along the gradient from ombrotrophic bog to rich fen, and that bog and fen indicator species fell within specific ranges of $\mathrm{pH}$ and $\mathrm{Ca}^{2+}$ concentrations. Hydrochemical factors such as $\mathrm{pH}$, alkalinity, electrical conductivity and $\mathrm{Ca}^{2+}$ and $\mathrm{HCO}_{3}^{-}$concentrations are therefore sometimes used to determine the boundary between ombrotrophic and minerotrophic conditions at the bog margin (Bragazza and Gerdol, 2002; Bourbonniere, 2009), although this may be a gradual change over several tens of metres without a discrete boundary (Sjörs and Gunnarsson, 2002; Howie and Tromp-van Meerveld, 2011). Cation concentrations (particularly $\mathrm{Ca}^{2+}$ and $\mathrm{Mg}^{2+}$ ), electrical conductivity and $\mathrm{pH}$ generally increase from the bog centre to the bog margin (Bubier, 1991; Bragazza et al., 2005; Richardson et al., 2010), which indicates the increasing influence of minerotrophic water towards the bog margin. The $\mathrm{Ca}: \mathrm{Mg}$ ratio may be used to locate the mineral soil water limit, whereby a ratio less than 1 is often taken as an indication of ombrotrophy (Waughman, 1980; Naucke et al., 1993); however, the specific $\mathrm{Ca}: \mathrm{Mg}$ ratio at the transition from ombrotrophic to minerotrophic conditions varies regionally and is related to distance from the ocean and annual precipitation (Waughman, 1980; Lähteenoja et al., 2009). This proxy for determining the mineral soil water limit should therefore only be useful where the ratio has been determined for several bogs in the region and precipitation (Shotyk, 1996).

Closely related to the hydrochemical conditions of a site is the ash content of the peat. The ash content of a peat sample is the amount of non-organic (i.e. mineral) material in the peat, and generally indicates the degree of influence of minerotrophic water (e.g. deposition of sediment from flooding or upland runoff). It may therefore be possible to delineate the lagg by mapping the ash content of near-surface peat (Bridgham et al., 1996; Rydin and Jeglum, 2006). However, this variable has been cited far less frequently as an indicator of the mineral soil water limit than the gradients in hydrochemistry and vegetation.

In addition to these local environmental gradients across the bog margin, there are also regional gradients in water chemistry. Regional gradients are largely caused by climate, but are also related to differences in precipitation chemistry between exposed, oceanic environments and more sheltered, inland regions. For example, Vitt et al. (1990) identified a clear gradient in surface water chemistry from the outer islands of northern British Columbia (BC) to the mainland, where the more oceanic islands were characterised by higher concentrations of $\mathrm{Na}^{+}$and $\mathrm{Cl}^{-}$. Riley (2011) observed a positive correlation between $\mathrm{pH}$ and distance from the Hudson Bay in central-eastern Canada. In contrast, Glaser et al. (1997) studied raised bogs across northwestern Minnesota (a relatively arid, continental region with no oceanic influences) and found no apparent correlation between the westward gradient in precipitation/evapotranspiration and hydrology or water chemistry.

Although these previous studies have shown gradients in hydrochemistry, hydrology and peat properties across the bog expanse-bog margin transition, little is known about how persistent these gradients are for bogs in a certain region, or how variable the conditions are at the margins of bogs in a certain region. The objective of this study was therefore to improve our understanding of the environmental gradients across bog margins, and to determine whether these gradients are consistent for bogs throughout coastal BC. Even though peatlands are common in coastal BC due to the cool, moist maritime climate that supports dense vegetation and slows decomposition (National Wetlands Working Group (NWWG), 1988), research on laggs has been limited to a study of peatlands on Vancouver Island (Golinski, 2004) and Burns Bog in the Fraser River delta (Howie et al., 2009a). Little information exists about regional gradients in bog hydrology and hydrochemistry in coastal BC. Understanding regional differences in lagg characteristics is needed to ensure an accurate understanding of ecohydrological functioning and sound management of bogs, as well as for bog restoration. As noted by Bragazza et al. (2005), it is not appropriate to compare bogs in geographically distinct 
regions because they are "not necessarily equivalent from an ecological point of view". The regionally specific results of this study add to the very limited international body of literature on the hydrological and hydrochemical gradients across the bog expanse-bog margin transition, and help us to understand the local and regional variability in lagg characteristics and thus to move towards a more holistic understanding of lagg structure and function.

\section{Study locations}

The 13 studied bogs are situated along the $\mathrm{BC}$ coast between 49 and $54^{\circ}$ north, within $20 \mathrm{~km}$ of the Pacific Ocean (including inlets), and are located less than $100 \mathrm{~m}$ above sea level (Fig. 1, Table 1). The bogs were studied in June and July 2010 and 2011, with the exception of Campbell River and Port McNeill bogs, which were studied in late May 2011 (Table 1). Three of the studied bogs are located near Prince Rupert (Diana Lake, Oliver Lake and Butze Rapids) (Fig. 1). On Graham Island (Haida Gwaii), research was conducted at three bogs (Mayer Lake, Drizzle Lake and Tow Hill). These six north coast bogs are underlain by acidic basaltic and sedimentary bedrock (NWWG, 1988). On Vancouver Island, studies took place at one bog on the west coast (Shorepine Bog) and two bogs on the east coast (Port McNeill and Campbell River). Shorepine and Campbell River bogs are underlain by sand, whereas Port McNeill bog is underlain by the same basaltic and sedimentary bedrock as the north coast bogs. Four additional bogs were studied in the Fraser Lowland region of southwestern BC (Burns Bog, Blaney Bog, Surrey Bend and Langley Bog). Burns Bog and Blaney Bog were mined for peat prior to the 1990s, and Surrey Bend has been disturbed by sewer and road construction, but the study sites were located in the undisturbed areas of these bogs. Burns Bog, Surrey Bend and Langley Bog formed on Fraser River deltaic deposits. Blaney Bog is located in the Pitt River valley wetland complex.

Wetlands on the Pacific coast of BC fall within two of the seven Canadian wetland regions: Pacific Oceanic and Pacific Temperate (Fig. 1). Haida Gwaii and the Prince Rupert area are located within the North Coast subregion of the Pacific Oceanic wetland region. The west coast of Vancouver Island is located in the South Coast subregion of the Pacific Oceanic wetland region. The North Coast Pacific Oceanic wetland subregion receives the most precipitation (Table 1), resulting in wetlands covering up to $75 \%$ of the landscape; common bog types in this region are sloping bogs (i.e. blanket bogs), basin bogs and riparian bogs (NWWG, 1988). The South Coast Pacific Oceanic wetland subregion is warmer, and most bogs are flat bogs or basin bogs. The other studied bogs are located in the Pacific Temperate wetland region (Fig. 1). Less than $5 \%$ of the landscape in this region is covered by wetlands (NWWG, 1988). The most common types of bog in the Pacific Temperate region are basin bogs and domed bogs.

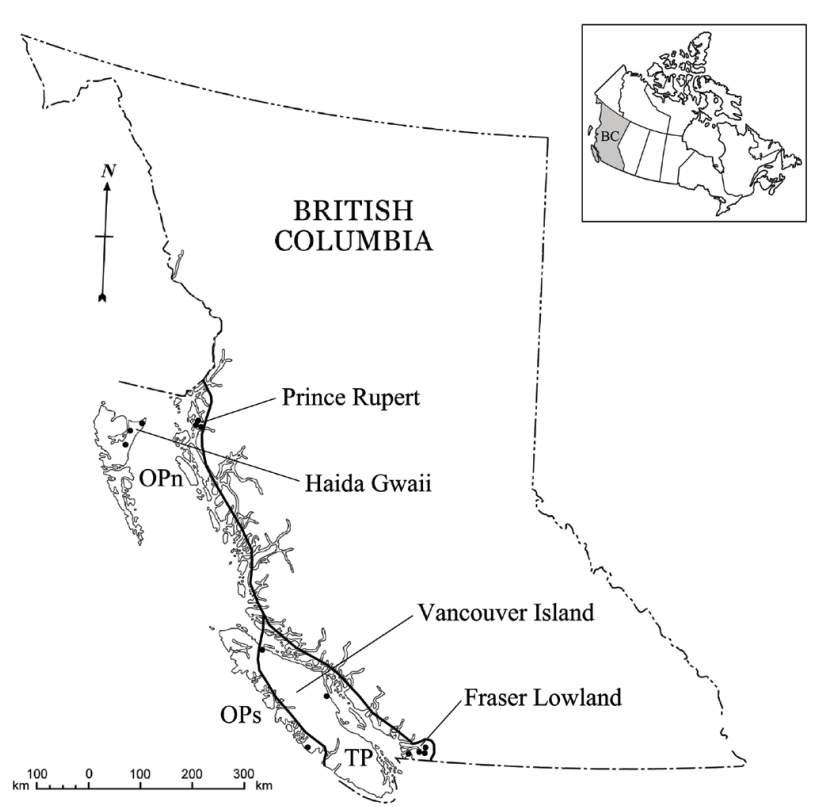

Fig. 1. Location of the research sites in British Columbia (BC) (black dots). Thick black lines represent the boundaries of the coastal wetland regions and subregions in this study: OPn represents the Pacific Oceanic, North Coast wetland subregion; OPs, the Pacific Oceanic, South Coast wetland subregion; and TP, the Pacific Temperate wetland region. Wetland region boundaries are from NWWG (1988). Inset: map of Canada.

\section{Methods}

A key goal of this study was to determine the variability in bog margin conditions in coastal BC. Because not all bogs are surrounded by a topographic depression and a moat-like lagg, a lagg was defined as the hydrological, hydrochemical and/or vegetative transition zone at the bog margin, regardless of whether an ecotone is present. At any given bog, a representative lagg ecotone, or the most representative bog margin condition, was chosen for study. "Confined" (Hulme, 1980) laggs supported a vegetative ecotone (e.g. shrub swamp or graminoid fen), whereas "unconfined" (Hulme, 1980) laggs were less well-defined and were characterised by a vegetative transition from open bog to forest.

We studied 17 transects, consisting of 5 sampling locations, across the laggs of the 13 bogs. Three of the bogs (Shorepine Bog, Burns Bog and Blaney Bog) contained multiple study transects (Table 1). The five sampling locations on each transect were as follows: (1) inside the bog ("BG"), (2) between the bog and lagg (closer to the bog: "R1"), (3) between the bog and lagg (closer to the lagg: "R2"), (4) approximate centre of the lagg ("LG") and (5) outside the bog ("MN") (Fig. 2). Vegetative characteristics were used to determine the five transect locations. BG sites were defined as Sphagnum-dominated heath, MN sites as the forest surrounding the bog, and LG sites as either Spiraea-dominated 
Table 1. Location and climate information for the 13 studied bogs. Bogs with more than one site code contained multiple study transects (one site code for each transect).

\begin{tabular}{|c|c|c|c|c|c|c|c|c|c|c|c|}
\hline $\begin{array}{l}\text { Site } \\
\text { Code }\end{array}$ & Site Name & $\begin{array}{l}\text { Latitude } \\
\text { (BG site) }\end{array}$ & $\begin{array}{l}\text { Longitude } \\
\text { (BG site) }\end{array}$ & $\begin{array}{r}\text { Elev. } \\
\text { (m a.s.1.) }\end{array}$ & $\begin{array}{r}\text { Radius } \\
\text { of bog } \\
(\mathrm{m})\end{array}$ & $\begin{array}{r}\text { Distance } \\
\text { to Ocean } \\
(\mathrm{km})\end{array}$ & $\begin{array}{r}\text { Average } \\
\text { Annual } \\
\text { Precip. } \\
(\mathrm{mm})\end{array}$ & $\begin{array}{r}\text { Average } \\
\text { Jul + Aug } \\
\text { Precip. } \\
(\mathrm{mm})\end{array}$ & $\begin{array}{r}\text { Precip. } 30 \\
\text { days before } \\
\text { measurements } \\
(\mathrm{mm})\end{array}$ & $\begin{array}{r}\text { Average } \\
\text { Annual } \\
\text { Temp. } .{ }^{b} \\
\left({ }^{\circ} \mathrm{C}\right)\end{array}$ & Date Measured \\
\hline $\mathrm{TH}$ & Tow Hill Boga & $54^{\circ} 3^{\prime} 53^{\prime \prime} \mathrm{N}$ & $131^{\circ} 48^{\prime} 50^{\prime \prime} \mathrm{W}$ & 19 & 405 & 0.1 & 1508 & 141 & 87 & 8.2 & 9 July 2010 \\
\hline ML & Mayer Lake Bog ${ }^{a}$ & $53^{\circ} 37^{\prime} 57^{\prime \prime} \mathrm{N}$ & $132^{\circ} 4^{\prime} 7^{\prime \prime} \mathrm{W}$ & 40 & 433 & 9.1 & 1508 & 141 & 88 & 8.2 & 11 July 2010 \\
\hline DT & Drizzle Lake Bog ${ }^{\mathrm{a}}$ & $53^{\circ} 55^{\prime} 41^{\prime \prime} \mathrm{N}$ & $132^{\circ} 6^{\prime} 26^{\prime \prime} \mathrm{W}$ & 58 & 439 & 0.7 & 1508 & 141 & 87 & 8.2 & 10 July 2010 \\
\hline $\mathrm{BR}$ & Butze Rapids Bog ${ }^{a}$ & $54^{\circ} 18^{\prime} 1^{\prime \prime} \mathrm{N}$ & $130^{\circ} 15^{\prime} 34^{\prime \prime} \mathrm{W}$ & 28 & 30 & 0.3 & 2594 & 270 & 86 & 7.1 & 19 July 2010 \\
\hline $\mathrm{OL}$ & Oliver Lake Bog ${ }^{\mathrm{a}}$ & $54^{\circ} 16^{\prime} 45^{\prime \prime} \mathrm{N}$ & $130^{\circ} 16^{\prime} 21^{\prime \prime} \mathrm{W}$ & 55 & 45 & 0.9 & 2594 & 270 & 86 & 7.1 & 21 July 2010 \\
\hline DL & Diana Lake Bog ${ }^{\mathrm{a}}$ & $54^{\circ} 14^{\prime} 19^{\prime \prime} \mathrm{N}$ & $130^{\circ} 9^{\prime} 22^{\prime \prime} \mathrm{W}$ & 36 & 73 & 8.2 & 2594 & 270 & 86 & 7.1 & 20 July 2010 \\
\hline PM & Port McNeill Bog ${ }^{\mathrm{a}}$ & $50^{\circ} 34^{\prime} 20^{\prime \prime} \mathrm{N}$ & $127^{\circ} 4^{\prime} 19^{\prime \prime} \mathrm{W}$ & 92 & 58 & 1.5 & 1869 & 122 & 72 & 8.3 & 30 May 2011 \\
\hline $\mathrm{CR}$ & Campbell River Bog ${ }^{\mathrm{a}}$ & $49^{\circ} 57^{\prime} 59^{\prime \prime} \mathrm{N}$ & $125^{\circ} 14^{\prime} 35^{\prime \prime} \mathrm{W}$ & 81 & 70 & 2.1 & 1452 & 89 & 88 & 8.6 & 31 May 2011 \\
\hline SPW, & Shorepine Bog & $49^{\circ} 0^{\prime} 46^{\prime \prime} \mathrm{N}$ & $125^{\circ} 39^{\prime} 30^{\prime \prime} \mathrm{W}$ & 22 & 97 & 1.2 & 3305 & 171 & 44 & 9.1 & 5 July 2011 \\
\hline SPE & & $49^{\circ} 0^{\prime} 46^{\prime \prime} \mathrm{N}$ & $125^{\circ} 39^{\prime} 28^{\prime \prime} \mathrm{W}$ & & & & & & 44 & & 5 July 2011 \\
\hline $\mathrm{CW}$ & Burns Bog & $49^{\circ} 7^{\prime} 27^{\prime \prime} \mathrm{N}$ & $123^{\circ} 0^{\prime} 36^{\prime \prime} \mathrm{W}$ & 4 & 3000 & 2.8 & 1008 & 67 & 46 & 9.6 & 20 June 2011 \\
\hline SW, & & $49^{\circ} 6^{\prime} 26^{\prime \prime} \mathrm{N}$ & $123^{\circ} 1^{\prime} 11^{\prime \prime} \mathrm{W}$ & & & & & & 48 & & 21 June 2011 \\
\hline DNR & & $49^{\circ} 8^{\prime} 16^{\prime \prime} \mathrm{N}$ & $122^{\circ} 56^{\prime} 11^{\prime \prime} \mathrm{W}$ & & & & & & 36 & & 18 June 2011 \\
\hline SB & Surrey Bend Bog & $49^{\circ} 12^{\prime} 17^{\prime \prime} \mathrm{N}$ & $122^{\circ} 44^{\prime} 47^{\prime \prime} \mathrm{W}$ & 6 & 400 & 11.6 & 1708 & 124 & 76 & 9.8 & 29 July 2011 \\
\hline LB & Langley Bog & $49^{\circ} 11^{\prime} 58^{\prime \prime} \mathrm{N}$ & $122^{\circ} 36^{\prime} 30^{\prime \prime} \mathrm{W}$ & 4 & 640 & 20.2 & 1708 & 124 & 74 & 9.8 & 30 July 2011 \\
\hline UP, & Blaney Bog & $49^{\circ} 15^{\prime} 35^{\prime \prime} \mathrm{N}$ & $122^{\circ} 35^{\prime} 17^{\prime \prime} \mathrm{W}$ & 5 & 144 & 19.5 & 2194 & 156 & 73 & 9.6 & 25 June 2011 \\
\hline FN & & $49^{\circ} 15^{\prime} 33^{\prime \prime} \mathrm{N}$ & $122^{\circ} 35^{\prime} 23^{\prime \prime} \mathrm{W}$ & & & & & & 73 & & 25 June 2011 \\
\hline
\end{tabular}

a Site name was created for this study based on nearby place name. ${ }^{\mathrm{b}}$ Environment Canada climate normals (1971-2000) (Environment Canada, 2012). Climate data for TH, ML, DT from Masset Inlet, BC; for BR, OL, DL from Prince Rupert, BC; for PM from Port Hardy, BC; for CR from Campbell River, BC; for SPW and SPE from Tofino, BC; for SW, CW, DNR from Vancouver International Airport; for SB and LB from Pitt Meadows, BC; and for UP and FN from Haney UBC Research Forest, BC.

or containing larger shrubs and trees than the bog. In some cases, the LG sites were topographically higher than the BG sites; this gradual upslope transition from raised bog or basin bog to blanket bog is common in the colder, wetter areas of the coastal $\mathrm{BC}$ region. In two instances (Tow Hill bog and Blaney Bog FN), the MN sites were lower than the LG sites, so that the LG sites did not receive surface runoff from the mineral soil. All locations were recorded with an Oregon 300 handheld GPS unit, accurate to $5 \mathrm{~m}$. All transects except those in Burns Bog were surveyed with a rod and level; the Burns Bog transect elevations were determined from lidar (light detection and ranging) data from September 2008, accurate to $15 \mathrm{~cm}$.

There were several exceptions to the five study locations per lagg transect. Butze Rapids bog is very small $(60 \mathrm{~m}$ diameter), so the transect was shortened to four sampling locations, with only one sampling point between the bog and lagg. The Burns Bog DNR transect contained no sampling locations between the bog and lagg because of a highway in that transition; however, there were two sampling locations in the lagg in order to investigate the differences between two distinct lagg plant communities (a Spiraea douglasii swamp and a forest on deep peat), resulting in four sampling locations on the DNR transect. The Burns Bog SW transect also had two sampling locations in the lagg to study differences in lagg species composition, resulting in a total of six sampling locations on that transect. The highway on the Burns Bog DNR transect was built with lightweight fill to "float" on the peat with culverts every $\sim 100 \mathrm{~m}$, designed to maintain the hydrologic connection across the highway. The wood chip road between the R2 and LG sites on the Burns Bog SW transect is highly porous. Based on a review of historic aerial photographs, these roads and other historic disturbances (e.g. peat mining and drainage) in other parts of the bog do not appear to affect the hydrological connection between the bog and the lagg at the selected study transects in a substantial way, although minor alterations from the historic conditions may have occurred.

Shallow piezometers were installed in hollows at each study location on the transects. The capped piezometers were $1.5 \mathrm{~m}$ long, $2.5 \mathrm{~cm}$ diameter schedule $40 \mathrm{PVC}$ pipe with a $0.40 \mathrm{~m}$ slotted section at the bottom. The depth of installation was based on the observed water level in the bore holes that were dug prior to piezometer installation. We aimed to place the slotted section of the piezometers as close to the water table as possible, while still ensuring an adequate volume of water for sample collection. The average base of the piezometers was $0.53 \mathrm{~m}$ (standard deviation: $0.20 \mathrm{~m}$ ) below the water table. The piezometers were purged twice and allowed to recharge for a minimum of $24 \mathrm{~h}$, but usually $3-7$ days. The water level was then measured using an electronic water level probe (Heron Instruments Little Dipper). It was assumed that the water level in the shallow piezometers with the screening just below the water table represented the water table because previous measurements in another area of Burns Bog showed that the difference between the water levels in a well and a shallow piezometer were small (mean: $0.8 \mathrm{~cm}$ ) (Howie and van Meerveld, 2012) and that this difference is similar to our water level measurement accuracy $(0.5 \mathrm{~cm})$ and the uncertainty in determining the ground surface in uneven terrain. Dipwells were not used in this study in order to avoid "short circuiting" of water from the bog surface, which would affect the hydrochemical measurements and could artificially raise the height of the water level in 

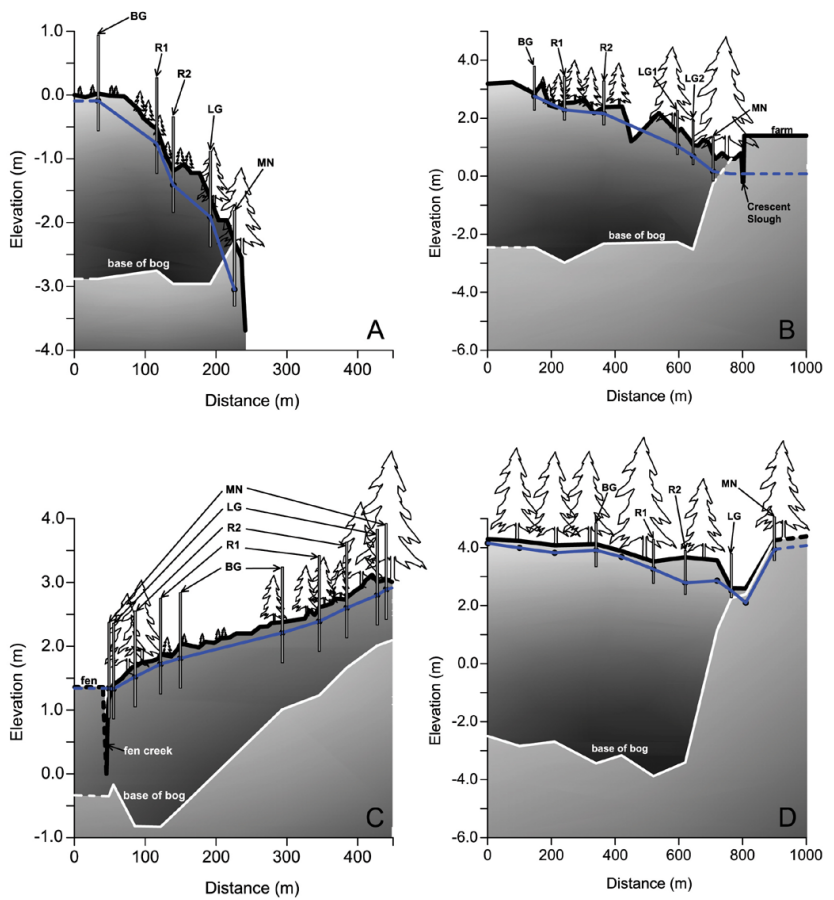

Fig. 2. Topographic profiles for (A) Tow Hill bog, (B) Burns Bog - SW, (C) Blaney Bog (left is FN; right, UP) and (D) Surrey Bend, with the locations of the sampling points. The thick black line represents the bog surface, the blue line with the symbols represents the water table and the white line the base of the peat. Dashed lines are estimated values. Panel (D) includes six additional water level measurements from another study (Baird, 2011). Vertical exaggeration: $90 x$. Tree height is not to scale, but trees are scaled relative to one another for each profile. Although it appears in (B) that Burns Bog is artificially confined, Crescent Slough is the natural boundary of the bog in this area; the mineral soil in the farm adjacent to Crescent Slough does not affect the transition from bog to lagg, although the ideal MN site would have been located in the historic vegetation beyond Crescent Slough, which is now replaced by mineral fill.

the well above the actual water table level during periods of heavy rainfall. We calculated the hydraulic gradient ("water table gradient") by dividing the difference in the elevations of the water levels at R1 and LG by the distance between $\mathrm{R} 1$ and LG, giving the percent slope of the water table. The elevation of the water table was calculated for each location on the transect by subtracting the depth to water table from the surface elevation that was determined by the topographic surveys.

Electrical conductivity and $\mathrm{pH}$ were measured at the top $10-15 \mathrm{~cm}$ of the water column inside the piezometers with a WTW Multiline P4 water quality meter after allowing the piezometers to recharge after the second purging. Electrical conductivity was compensated for the $\mathrm{H}^{+}$concentration using $\mathrm{EC}_{\text {corr }}=\mathrm{EC}_{\text {measured }}-\mathrm{EC}_{\mathrm{H}}^{+}$, where $\mathrm{EC}_{\mathrm{H}}^{+}=3.49 \times 10^{5} \times$ $10^{-\mathrm{pH}}$ and $3.49 \times 10^{5}$ is the conversion factor for field measurements standardised to $25^{\circ} \mathrm{C}$ (Rydin and Jeglum, 2006).
Water samples were collected for laboratory analysis from all piezometers using a low-flow peristaltic pump (Global Water SP200) and plastic HDPE bottles. Water was pumped from the piezometers at the rate of recharge whenever possible. Samples were filtered with a $0.45 \mu \mathrm{m}$ filter within four hours of sample collection in 2010 and in the field in 2011. The water samples for cation analysis were preserved with nitric acid. Samples were kept on ice and refrigerated until delivery to the Pacific Environmental Science Centre (North Vancouver, BC) and were analysed for $\mathrm{Ca}^{2+}, \mathrm{Mg}^{2+}$ and $\mathrm{Na}^{+}$ concentrations (by inductively coupled plasma spectrometry) and acidity (by titration).

At each study location along the transect, peat samples were collected at 10,50 and $100 \mathrm{~cm}$ below the surface with an Eijkelkamp flag corer. For each depth, the von Post level of humification was determined in the field using the method described by Rydin and Jeglum (2006). Peat samples from the three depths were wrapped in plastic wrap and sealed in plastic freezer bags for laboratory analysis, transported in a cooler and refrigerated up to one month, or frozen, until laboratory analysis. In the lab, each sample was weighed, ovendried at $105^{\circ} \mathrm{C}$ for $24 \mathrm{~h}$ and re-weighed, and then dry-ashed in a $550^{\circ} \mathrm{C}$ oven for $24 \mathrm{~h}$ and re-weighed a final time to determine the amount of mineral (i.e. non-organic) material in the sample. The depth of peat was determined at each coring location as well.

The measurements were taken in June/July (and late May at Campbell River and Port McNeill) because this was determined to be the most stable time of the year for sampling. Since ombrotrophic bogs receive all (or most) of their water from atmospheric sources, the fluctuation of the water table in bogs is closely linked to precipitation (Egglesmann et al., 1993). For coastal BC bogs, the seasonal rise and fall of the water table is quite similar between years; the water table is highest in winter, gradually declines through the spring and summer, and is lowest at the end of the summer (i.e. August/September), following the pattern of precipitation (Golinski, 2004; Howie et al., 2009b). Therefore, we measured depth to water table in each bog at roughly the same time of year (June/July) to ensure relatively comparable conditions.

Rainfall in coastal BC is generally lowest between May and August; thus, sampling in this period gives the highest probability of avoiding significant rainfall events between purging and sampling that could dilute near-surface pore water and result in measurements that are not comparable to sites that did not experience the same precipitation prior to sampling. August is the driest month in this region, so sampling was avoided during this month to minimise the concentrating effect of evapotranspiration. Electrical conductivity, $\mathrm{pH}$ and the concentrations of major cations (e.g. $\mathrm{Na}^{+}$and $\mathrm{Mg}^{2+}$ ) are generally fairly stable over time (Howie, 2013). For example, in a $1.5 \mathrm{yr}$ study of bogs in southern coastal BC, Howie (2013) showed that measurements in June/July were generally within 0.25 of the average for $\mathrm{pH}$ for the 
measurement period, and within $65 \mu \mathrm{Scm}^{-1}$ of the average for $\mathrm{EC}_{\text {corr }}\left(85 \%\right.$ of $\mathrm{EC}_{\text {corr }}$ measurements were within $25 \mu \mathrm{S} \mathrm{cm}^{-1}$ of the average). Biweekly and monthly measurements of near-surface pore water in an Alberta bog showed that the range in $\mathrm{pH}$ was less than 0.5 , the range for $\mathrm{pH}$ corrected electrical conductivity was less than $50 \mu \mathrm{S} \mathrm{cm}^{-1}$, and the range was less than $5 \mathrm{mg} \mathrm{L}^{-1}$ for $\mathrm{Ca}^{2+}$ concentrations and less than $2 \mathrm{mg} \mathrm{L}^{-1}$ for $\mathrm{Na}^{+}$and $\mathrm{Mg}^{2+}$ concentrations (Vitt et al., 1995). Therefore, it was assumed that a onetime sampling campaign was sufficient to characterise the hydrochemical gradients across the bog expanse-bog margin transition.

Spearman rank $\left(r_{\mathrm{s}}\right)$ and Pearson linear $\left(r^{2}\right)$ correlations between the measured variables were determined. Spearman rank correlations were not performed if the number of observations was less than five. All correlations described in the text are Spearman rank correlations, unless specifically noted as Pearson linear correlations. We used a two-tailed $t$ test to determine if the differences in the measured variables between the two wetland regions were significant. A significance level of 0.05 was used for all analyses, although Table 3 also shows correlation results for other significance levels.

\section{Results and discussion}

\subsection{Depth to water table}

\subsubsection{Local variation}

The water table was located within $25 \mathrm{~cm}$ of the surface for all studied BG sites. The depth to water table in June/July generally increased across the transition from bog to forest, except where there was a topographic depression that caused water to pond at the bog margin. Depth to water table was smallest for the BG sites (mean: $15 \mathrm{~cm}$ below the surface), slightly larger across the transition from bog to lagg (mean for R1, R2 and LG sites: $23 \mathrm{~cm}$ ) and deepest in the MN sites (mean: $32 \mathrm{~cm}$ ) (Table 2; Fig. 2a,b). The trend of increasing depth to water table towards the margin of raised bogs is well established (Ingram, 1983; Damman, 1986; Schouten, 2002). However, the variable topography of the individual bogs resulted in this trend being less clear on a site-by-site basis. Spearman rank correlation between depth to water table and position on the transect was significant for only 4 of 14 transects (three transects had less than five data points and were not included in the analyses). In some locations (e.g. Mayer Lake, Surrey Bend), the water table was close to the surface in the lagg, due to the lagg being topographically constrained between the bog and an adjacent upland (Fig. 2d). The morphology at the bog margin is thus a key factor controlling the position of the water table.

The (absolute) water table elevation declined from the bog outwards in most cases (10 out of 16 transects), but increased towards the lagg in other cases (6 out of 16 transects). The hydraulic gradient between the R1 and LG sites ranged from $-7.0 \%$ to $5.6 \%$ (mean and median: $-0.03 \%$; standard deviation: $2.4 \%$ ) and generally followed the surface gradient (Table 2). In locations where the lagg is topographically higher than the bog, one might question whether these study sites are actually bogs since surface water could flow from the lagg to the bog. As noted earlier, blanket bogs are common in coastal BC, which can be ombrotrophic despite having formed on sloping ground. However, it is also possible that some of the studied sites are transitional between bog and poor fen, rather than purely ombrotrophic. Minor flow reversals (Devito et al., 1997) are also possible in these sites, but the high rainfall in the regions that support blanket bogs is expected to "flush" minerotrophic water from the peat.

\subsubsection{Regional variation}

There was no statistically significant difference in early summer depth to water table between the wetland regions (Table 2). Mean (and median) depth to water table for the BG sites was $14 \mathrm{~cm}(15 \mathrm{~cm})$ and $16 \mathrm{~cm}(19 \mathrm{~cm})$ for the Pacific Temperate and Pacific Oceanic wetland regions, respectively. The water table in bogs in the Pacific Temperate wetland region was slightly closer to the surface, probably because these bogs were surveyed in late May and June, whereas the bogs in the Pacific Oceanic wetland region were studied in July. In coastal BC, the water table in bogs can be expected to drop 5-10 cm over the month of June, depending on rainfall (Howie et al., 2009b; Howie and van Meerveld, 2012).

The water table was relatively high in $\mathrm{MN}$ sites in the Prince Rupert area (mean: $22 \mathrm{~cm}$ below the surface; median: $24 \mathrm{~cm}$ ) compared to the other regions; the mean (and median) depth to water table was $41 \mathrm{~cm}(26 \mathrm{~cm}), 37 \mathrm{~cm}(40 \mathrm{~cm})$ and $31 \mathrm{~cm}(33 \mathrm{~cm})$ below the surface for the Haida Gwaii, Vancouver Island and Fraser Lowland bogs, respectively. This may be partly explained by the forested sloping bogs that are prevalent in the Prince Rupert area. This type of bog can persist in this region due to the high annual precipitation and relatively low temperatures (Table 1 ). The comparatively high water table in the MN sites of Butze Rapids and Diana Lake was probably due to the transects being installed across a transition from open bog to sloping bog, instead of transitioning to a true minerotrophic forest. The piezometer in the Oliver Lake MN site was installed in a topographic depression on a slope above the bog, resulting in a water table close to the surface. 
Table 2. Depth of the water table below the surface $(\mathrm{cm})$ for all study transects. Negative values indicate that the water table was above the ground surface. For the DNR transect, the data shown under R2 are from the second LG site on this transect. Also shown is the surface gradient and the hydraulic gradient (\%) between the R1 and LG sites; positive values indicate that the ground surface or water table at the LG site was higher than at the R1 site, and negative values indicate that the ground surface or water table at the LG site was lower than at the $\mathrm{R} 1$ site.

\begin{tabular}{|c|c|c|c|c|c|c|c|c|c|c|}
\hline \multirow{2}{*}{$\begin{array}{l}\text { Geographic } \\
\text { Location and } \\
\text { Bog Name }\end{array}$} & & pth to & Nater & able ( & & \multirow{2}{*}{$\begin{array}{r}\text { Surface } \\
\text { Gradient: } \\
\text { R1 to LG } \\
(\%)\end{array}$} & \multirow{2}{*}{$\begin{array}{r}\text { Hydraulic } \\
\text { Gradient: } \\
\text { R1 to LG } \\
(\%)\end{array}$} & Peat & (m) & \multirow{2}{*}{$\begin{array}{r}\text { Cluster } \\
\text { (1 or } 2 \text { ) for } \\
\text { LG Site } \\
\text { (see Fig. 9) }\end{array}$} \\
\hline & $\mathrm{BG}$ & $\mathrm{R} 1$ & $\mathrm{R} 2$ & LG & $\mathrm{MN}$ & & & $\mathrm{BG}$ & $\mathrm{LG}$ & \\
\hline Tow Hill & 11 & 25 & 22 & 31 & 75 & -1.1 & -1.5 & 2.9 & 1.4 & 2 \\
\hline Mayer Lake & 22 & 26 & 28 & 7 & 21 & -1.4 & -0.9 & 3.5 & 0.7 & 1 \\
\hline Drizzle Lake & 22 & 25 & 11 & 38 & 26 & 0.7 & 0.4 & 2.1 & 0.7 & 2 \\
\hline Butze Rapids & 9 & 36 & - & 19 & 24 & -1.4 & 0.5 & 2.6 & 1.8 & 1 \\
\hline Diana Lake & 18 & 36 & 48 & 21 & 24 & -9.2 & -7.0 & 1.1 & 0.8 & 2 \\
\hline Oliver Lake ${ }^{\mathrm{a}}$ & 10 & 17 & 45 & 50 & 18 & 6.9 & 5.6 & 1.4 & 1.6 & 2 \\
\hline Port McNeill & 19 & 23 & $59^{\mathrm{b}}$ & 37 & 46 & -0.1 & -0.6 & 2.6 & 1.0 & 1 \\
\hline Campbell River & 1 & 1 & -3 & -2 & 40 & 0.1 & 0.1 & 1.5 & 0.4 & 2 \\
\hline Shorepine West & 19 & $41^{\mathrm{b}}$ & 23 & 14 & 21 & 0.3 & 0.4 & 0.6 & 0.7 & 1 \\
\hline Shorepine East & 20 & 25 & 21 & 38 & 39 & 0.1 & -1.0 & 0.3 & 0.6 & 2 \\
\hline Burns Bog - SW & 13 & 32 & 30 & 36 & 55 & -0.4 & -0.4 & 5.3 & 3.8 & 1 \\
\hline Burns Bog $-\mathrm{CW}$ & 5 & 18 & 5 & 8 & 67 & -0.2 & -0.1 & 3.6 & 0.6 & 1 \\
\hline Burns Bog - DNR & - & - & 9 & 29 & 23 & - & - & 2.6 & 9.0 & 1,2 \\
\hline Blaney Bog - UP & 17 & 24 & 22 & 23 & 19 & 0.5 & 0.5 & 3.9 & 2.4 & 2 \\
\hline Blaney Bog - FN & 25 & 14 & 14 & 4 & -22 & -0.7 & -0.7 & 3.5 & 2.0 & 1 \\
\hline Surrey Bend & 25 & 20 & 13 & 3 & 44 & -0.3 & -0.3 & 7.6 & 0.3 & 2 \\
\hline Langley Bog & 11 & 11 & 17 & 41 & - & -0.1 & -0.3 & 7.5 & 0.3 & 1 \\
\hline Mean & 15 & 23 & 23 & 23 & 32 & -0.4 & -0.3 & 3.1 & 1.7 & \\
\hline Median & 18 & 24 & 21 & 23 & 25 & -0.1 & -0.3 & 2.6 & 0.8 & \\
\hline
\end{tabular}

${ }^{\mathrm{a}}$ This bog is located partly on a steep slope and thus appears to be a basin bog or a flat bog that has extended into a sloping bog at its margin. ${ }^{b}$ It is possible that these piezometers had not fully recharged at the time of measurement. For this reason, the hydraulic gradient for Shorepine West was calculated using the R2 water table elevation.

\subsection{Peat characteristics}

\subsubsection{Local variation}

As expected, peat depth decreased from the centre of the bog to the margin of the bog for all regions (Fig. 3). There was a significant correlation between peat depth and position on the transect for the Haida Gwaii, Vancouver Island and Fraser Lowland bogs, but not for the Prince Rupert bogs, when the transects were combined by region. The correlations were significant for 13 of the 17 individual transects. Some MN sites in the Prince Rupert and Fraser Lowland bogs were peaty, whereas all of the MN sites on the Haida Gwaii and Vancouver Island transects were located in mineral soil (Fig. 3). In the Fraser Lowland, this was due to the mineral soil adjacent to the bogs being too rocky to install a piezometer, so the MN study site was instead located in wet, partly organic soil at the outer margin of the functional lagg, as close as possible to the true mineral soil. The plant species in these MN sites (e.g. Maianthemum dilatatum (Wood) Nels. \& Macbr., Physocarpus capitatus (Pursh)
Kuntze) indicated a higher concentration of nutrients, which is more representative of mineral soil conditions compared to the LG sites on the transects (e.g. Spiraea douglasii Hook., Gaultheria shallon Pursh). For one transect (Blaney Bog FN), the MN site was located in a large fen at the edge of the bog (Fig. 2c). In Prince Rupert, on the other hand, it is common for open bogs to transition into forested sloping bogs (NWWG, 1988); the transect at Butze Rapids bog, for example, cut through this type of transition. These MN sites therefore contain more organic matter than the other MN sites.

Bog peat normally contains less than $5 \%$ ash content by dry weight, whereas fen peat may have an ash content of up to $35 \%$ (Stoneman and Brooks, 1997; de Vleeschouwer et al., 2010). Our results for BG site peat samples from $10 \mathrm{~cm}$ depth generally agreed with these values, except for five bogs (from all regions, except Prince Rupert) that had ash contents between 5 and $10 \%$. Peat samples from 50 and $100 \mathrm{~cm}$ showed similar results; BG site peat samples contained less than $6 \%$ ash content at $50 \mathrm{~cm}$ depth (except for Shorepine Bog) and less than $7 \%$ ash content at $100 \mathrm{~cm}$ depth (except for Shorepine Bog). The 50 and $100 \mathrm{~cm}$ samples from 

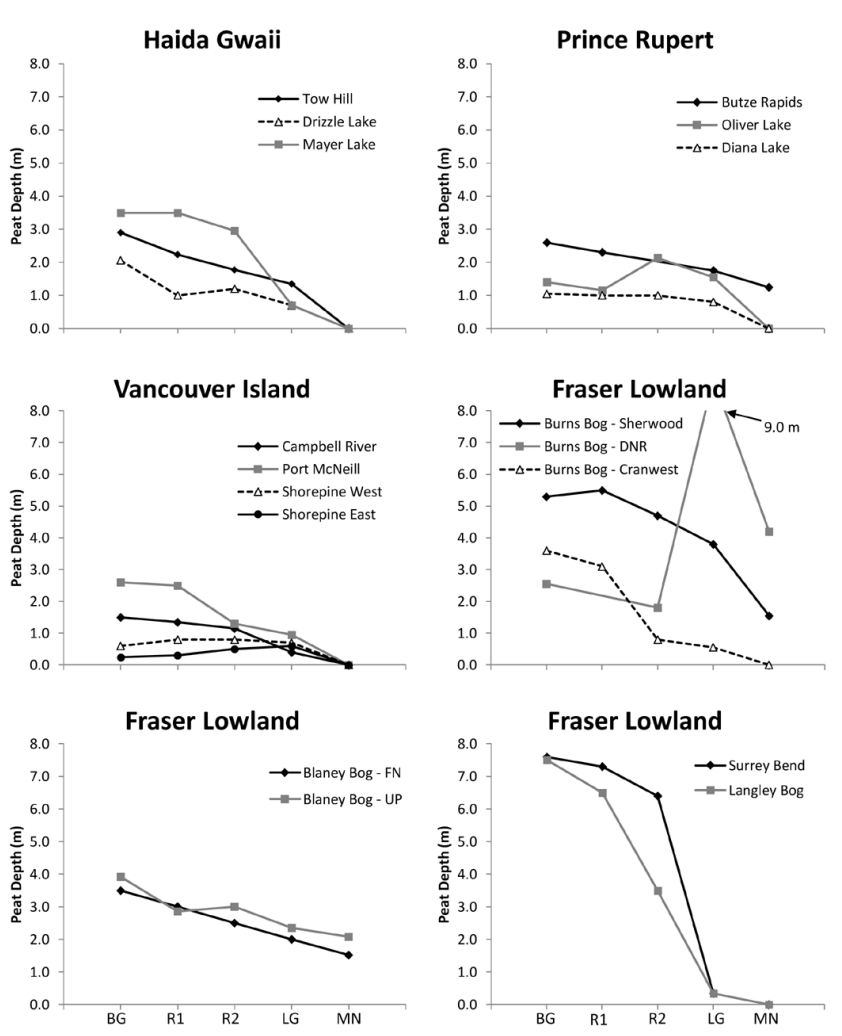

Fig. 3. Peat depth (m) across the study transects.

Shorepine Bog contained significant amounts of sand, which is the substrate beneath the shallow ( 25 and $60 \mathrm{~cm}$ deep at the two BG sites) peat at Shorepine Bog.

Mean ash content increased across the transition from bog to forest for all regions (Fig. 4). Ash content was 0-56 (mean: 6) and 0-73 (mean: 13) times higher in the lagg than the bog at 10 and $50 \mathrm{~cm}$ depths, respectively. These results are similar to those of Gorham (1950), who found ash content at the outer minerotrophic edge of the lagg of a raised bog near Uppsala to be 5 times greater than the ash content closer to the centre of the bog. Peat samples from the LG sites contained less than $35 \%$ ash content at $10 \mathrm{~cm}$ depth, with the exception of Surrey Bend bog (50\%), Campbell River bog (52\%) and Drizzle Lake bog (58\%). The mean ash content at $10 \mathrm{~cm}$ depth for all LG sites, excluding Surrey Bend, Campbell River and Drizzle Lake was $5 \%$ (standard deviation: $3 \%$ ), which falls within the range of ash content for fen peat (Stoneman and Brooks, 1997; de Vleeschouwer et al., 2010).

Ash content was expected to increase with depth below the surface. However, this was only the case for $44 \%$ of the cores, mostly on Vancouver Island and in the Fraser Lowland. In many cases, ash content was relatively constant, or decreased with depth below the surface. Ash content increased with depth twice as often in the LG sites compared to the other locations on the study transects. The lagg peat probably received greater amounts of sediment from adjacent
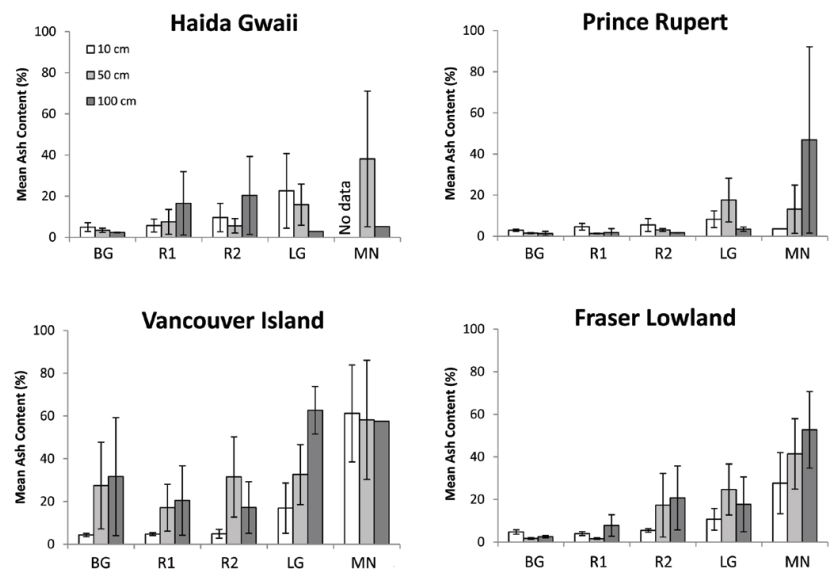

Fig. 4. Mean ash content (\% dry weight) in peat samples from three depths below the surface $(10,50$ and $100 \mathrm{~cm})$ for the four study regions. The samples from Shorepine Bog (a shallow bog: peat depth $<0.8 \mathrm{~m}$ ) explain the significantly higher mean ash content values shown for Vancouver Island. Whiskers represent one standard error.

upland areas during the accumulation of peat in the bog and lagg. The increasing ash content with depth in the lagg is probably also related to the shallower peat in the lagg, so that the deeper samples were influenced more by mineral soil. Laggs in which the ash content increased with depth had an average peat depth of $0.81 \mathrm{~m}$, whereas laggs where ash content did not increase with depth had an average peat depth of $2.32 \mathrm{~m}$. However, for the other (non-lagg) locations on the transects, depth of peat at the sample site was not related to whether the ash content of the peat cores increased with depth or not. The most consistent increase in ash content with depth was found for the Shorepine Bog transects, but this bog is shallow $(<0.8 \mathrm{~m})$ so that the deeper samples were influenced by the sand beneath the peat.

It is generally thought that the level of humification of peat increases with depth below the bog surface (Schouten, 2002; Sherwood et al., 2013), although it has also been shown (e.g. Baird et al., 2008) that this trend is not as clear or consistent as might be expected. Our von Post measurements showed a trend of increasing humification with depth in $72 \%$ of the cores, but no change (19\%) or decreasing humification (9\%) in the remainder of the cores (Fig. 5). Humification can also be expected to increase across the transition from bog to lagg, because rand and lagg peat is generally more aerated due to a lower water table and more oxidation and decomposition. For example, Bubier (1991) observed that peat from the upper $40 \mathrm{~cm}$ of an open bog site was "non-humified", whereas peat in the upper $20 \mathrm{~cm}$ of the adjacent rand forest was "moderately humified". We found increasing von Post humification from the bog to the lagg in only 33,60 and $47 \%$ of the transects at 10,50 and $100 \mathrm{~cm}$ depth, respectively. Therefore, von Post humification displayed a more consistent increase with depth than with distance across the transect. 
Table 3. Pearson linear correlation $\left(r^{2}\right.$, shaded upper half of table) and Spearman rank correlation $\left(r_{\mathrm{s}}\right.$, unshaded lower half of table) coefficients for the hydrochemical parameters measured at the BG sites. For coefficients in bold, $p<0.01$; for plain text coefficients, $0.01<p<0.05$ and for coefficients in italics, $0.05<p<0.1$.

\begin{tabular}{|c|c|c|c|c|c|c|c|c|c|c|c|c|}
\hline & & \multicolumn{11}{|c|}{ Pearson linear correlation $\left(r^{2}\right)$} \\
\hline & & LAT & WR & PD & $P$ & $T$ & $\mathrm{pH}$ & $\mathrm{EC}_{\text {corr }}$ & $\mathrm{Ca}^{2+}$ & $\mathrm{Mg}^{2+}$ & $\mathrm{Na}^{+}$ & Acid. \\
\hline \multirow{11}{*}{ 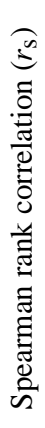 } & LAT & & 0.826 & - & - & 0.819 & 0.377 & - & - & - & - & 0.844 \\
\hline & WR & -0.630 & & 0.226 & - & 0.689 & 0.617 & - & - & - & - & 0.767 \\
\hline & $\mathrm{PD}$ & - & 0.510 & & 0.259 & 0.303 & 0.446 & - & - & - & - & 0.328 \\
\hline & $P$ & - & - & -0.487 & & - & 0.263 & - & - & - & - & 0.276 \\
\hline & $T$ & -0.772 & 0.855 & 0.626 & - & & 0.375 & - & - & - & - & 0.746 \\
\hline & $\mathrm{pH}$ & 0.461 & -0.835 & -0.614 & 0.431 & -0.693 & & - & - & - & 0.207 & 0.645 \\
\hline & $\mathrm{EC}_{\text {corr }}$ & - & - & - & - & - & - & & - & 0.208 & 0.231 & - \\
\hline & $\mathrm{Ca}^{2+}$ & -0.447 & - & - & - & - & - & - & & - & - & - \\
\hline & $\mathrm{Mg}^{2+}$ & - & - & - & -0.430 & - & - & 0.700 & - & & 0.697 & - \\
\hline & $\mathrm{Na}^{+}$ & - & - & - & - & - & - & 0.800 & - & 0.827 & & - \\
\hline & Acid. & $-\mathbf{0 . 9 5 3}$ & -0.860 & 0.675 & -0.470 & 0.861 & -0.766 & - & - & - & - & \\
\hline
\end{tabular}

LAT represents latitude; $\mathrm{WR}$, wetland region; $\mathrm{PD}$, peat depth; $P$, mean annual precipitation; $T$, mean annual temperature.

\subsubsection{Regional variation}

There was a significant difference in peat depth between the Pacific Oceanic and Pacific Temperate wetland regions. Peat depth at the BG sites was $<0.6 \mathrm{~m}$ in the South Coast Pacific Oceanic wetland subregion, and more variable in the North Coast Pacific Oceanic wetland subregion (1.1-3.5 m) and Pacific Temperate $(1.5-7.6 \mathrm{~m})$ wetland region. Average peat thickness at the BG sites in the Fraser Lowland bogs $(4.9 \mathrm{~m})$ was greater than in the Haida Gwaii $(2.8 \mathrm{~m})$, Prince Rupert $(1.7 \mathrm{~m})$ and Vancouver Island $(1.2 \mathrm{~m})$ bogs.

Peat depth was significantly correlated with mean annual precipitation and mean annual temperature (Table 3), which are the main factors used to designate the different wetland regions. The deepest bogs in our study are located where precipitation is lowest and temperature is highest. In general, the height of raised bogs increases as precipitation increases (Damman, 1979; Clymo, 1984; Ingram, 1983). Our results are thus not in agreement with this general trend. Bogs also increase in height with increasing mean annual temperature, as long as the water table is high enough that Sphagnum can access water during the growing season (Damman, 1979); our results agree with this observation. However, the height of the peat dome does not only depend on climate alone but is also related to the diameter of the bog (Hobbs, 1986; Clymo, 1984; Ingram, 1983). Most bogs in coastal BC are relatively small in comparison to those in other areas of Canada, in part due to topographic constraints in this mountainous region (NWWG, 1988). The large bogs of the Fraser Lowland, in contrast, formed on relatively flat fluvial material. Large bogs also cover a large part of the low-relief landscape of Graham Island, Haida Gwaii (NWWG, 1988). Despite receiving less precipitation than the Prince Rupert area or the west coast of Vancouver Island, the studied Fraser Lowland and Haida Gwaii bogs are larger than the other bogs (Table 1); the larger diameter of these bogs could be the main factor for their greater peat depths. We found a significant correlation between bog radius and peat depth $\left(r_{\mathrm{s}}=0.58\right)$, and a non-significant correlation between bog radius and bog height above the lagg $\left(r_{\mathrm{s}}=0.50, p=0.082\right)$. Three of the Fraser Lowland bogs were subject to past disturbance, but the study sites were intentionally located in undisturbed areas of the bogs; thus, the disturbed areas of these bogs would have only minor effects on the study sites and the correlation between bog radius and dome height.

Riley (2011) found that peat depth of Hudson Bay peatlands was related to time since glaciation and subsequent isostatic rebound. Coastal British Columbia was glaciated until the end of the Pleistocene (10000 yr BP); the Cordilleran Ice Sheet covered the mainland and Vancouver Island, whereas Haida Gwaii was covered by its own set of glaciers and large areas may have been ice-free (Clague, 1989; Vitt et al., 1990). Some peat deposits in Haida Gwaii predate the end of the last glaciation, supporting the hypothesis that this area was not entirely glaciated (Mathewes and Clague, 1982). Deglaciation in the Prince Rupert area occurred around $12700 \pm 120$ BP (Mathewes and Clague, 1982). Sphagnum growth and bog development near Port McNeill occurred around $7000 \mathrm{BP}$ as the climate became wetter (Hebda, 1983). The Fraser River delta formed between 7500 and $5000 \mathrm{BP}$ (Clague et al., 1991), and formation of peat in the delta occurred between 5500 and 3500 BP (Hebda, 1977; Clague et al., 1991). Thus, time since last glaciation does not appear to be a primary factor for the observed differences in peat depth in this region.

There was no significant difference in mean ash content at any of the sampled depths for the BG or LG sites between the Pacific Oceanic and Pacific Temperate wetland regions. 


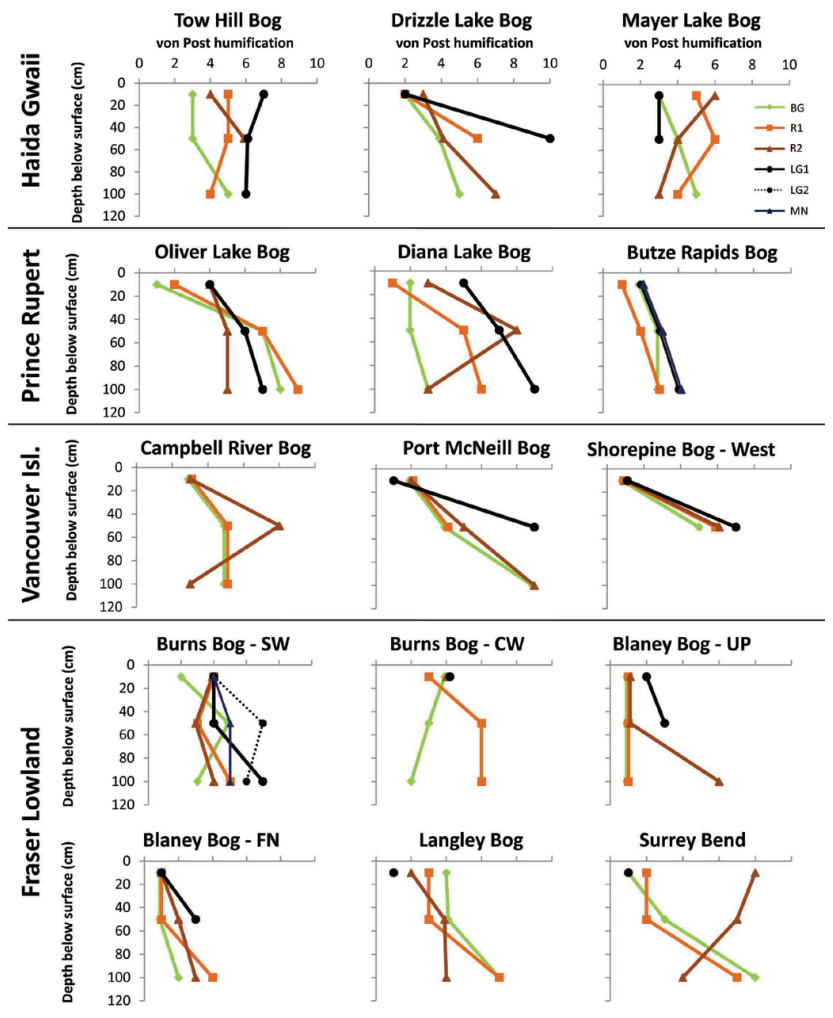

Fig. 5. von Post humification as a function of depth below the surface for all transects. "Shorepine Bog - East" and "Burns Bog DNR" are not included in this graph due to missing data points. Overlapping von Post values are offset by 0.1 to improve visual clarity of the figure.

In all 50 and $100 \mathrm{~cm}$ LG site peat samples from Prince Rupert and Haida Gwaii, ash content was less than $35 \%$, except for Drizzle Lake bog, which had $36 \%$ ash content at $50 \mathrm{~cm}$ depth at the LG site (and no sample from $100 \mathrm{~cm}$ depth). In contrast, only 43 and $81 \%$ of deeper LG site samples from Vancouver Island and the Fraser Lowland, respectively, had less than $35 \%$ ash content. The laggs of north coast bogs contain more organic matter and appear to be less influenced by adjacent and underlying mineral soils, whereas some laggs on Vancouver Island and in the Fraser Lowland may have received greater amounts of sediment from adjacent upland areas and river floodplains (prior to dyking) during their development. There was no clear difference in level of von Post humification between the four study regions (Fig. 5).

\subsection{Hydrochemistry}

\subsubsection{Local variation}

Pore water $\mathrm{pH}$ generally increased across the bog expansebog margin transition, with the lagg $\mathrm{pH}$ being transitional between the bog and forest (Fig. 6). A significant correlation between $\mathrm{pH}$ and location on the transect was found for all regions except Vancouver Island when all bogs in a region were
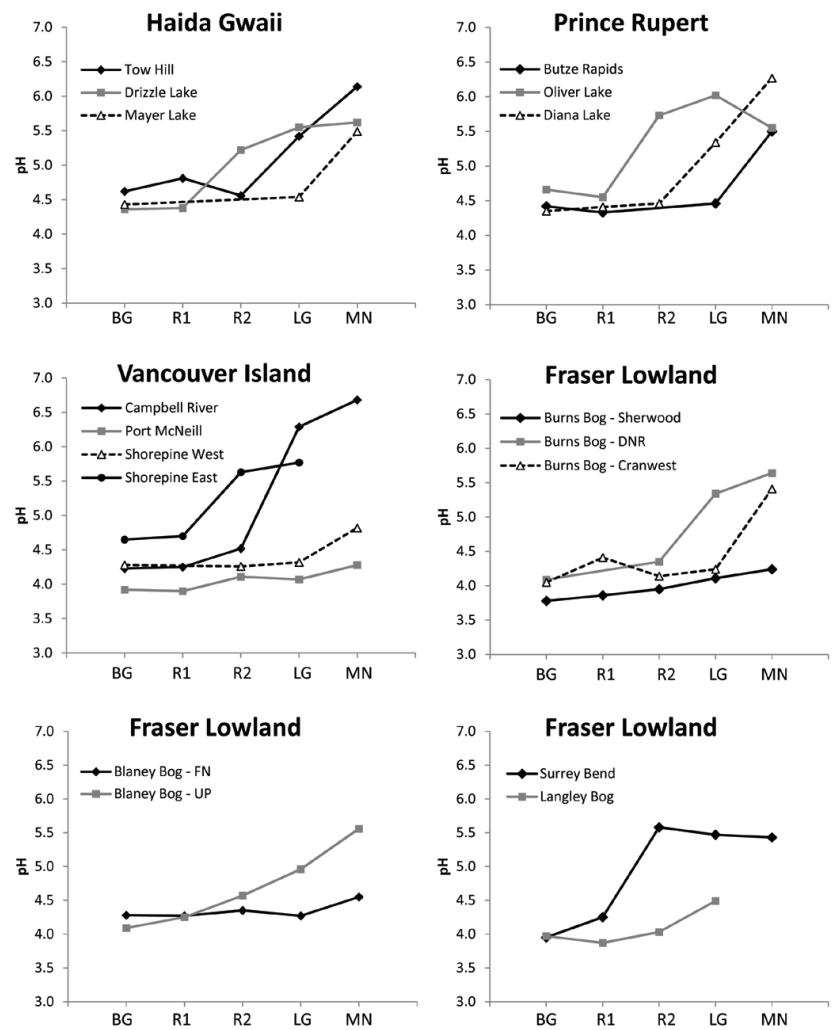

Fig. 6. Variation in $\mathrm{pH}$ across the study transects.

analysed together, but the correlation was only significant for 5 of the 17 individual transects (Drizzle Lake, Diana Lake, Campbell River, Burns Bog SW, Blaney Bog UP). Similar to $\mathrm{pH}, \mathrm{Ca}^{2+}$ concentrations generally increased across the transition from bog to forest (Fig. 7). However, this correlation was even less consistent than that of $\mathrm{pH}$. The correlation between $\mathrm{Ca}^{2+}$ concentration and position on the transect was only significant for the Prince Rupert and the Fraser Lowland bogs when all bogs in a region were combined, and for only 1 out of 9 tested transects (Blaney Bog UP). Corrected electrical conductivity $\left(\mathrm{EC}_{\mathrm{corr}}\right)$ also tended to increase across the transects from bog to forest (Fig. 8). There was a significant correlation between $\mathrm{EC}_{\text {corr }}$ and location on the transect when bogs were combined by region, except for Vancouver Island, but not often for the individual transects (only 3 out of 13 tested transects: Tow Hill, Drizzle Lake, Diana Lake). $\mathrm{Mg}^{2+}$ and $\mathrm{Na}^{+}$increased from bog to forest for 47 and $35 \%$ of the transects, respectively, but the Spearman rank correlation between location on the transect was only significant for two bogs (Burns Bog SW and Blaney Bog UP) for $\mathrm{Mg}^{2+}$ and for none of the transects for $\mathrm{Na}^{+}$. Bubier (1991) found that $\mathrm{pH}, \mathrm{EC}_{\text {corr }}$ and $\mathrm{Ca}^{2+}$ and $\mathrm{Mg}^{2+}$ concentrations increased significantly along a transect from an open bog to a lagg creek in Vermont. Similarly, Bragazza et al. (2005) observed a higher $\mathrm{pH}$ and higher concentrations of $\mathrm{Ca}^{2+}$ and $\mathrm{Mg}^{2+}$ in the lagg fens of an Italian and a Swedish bog compared to 

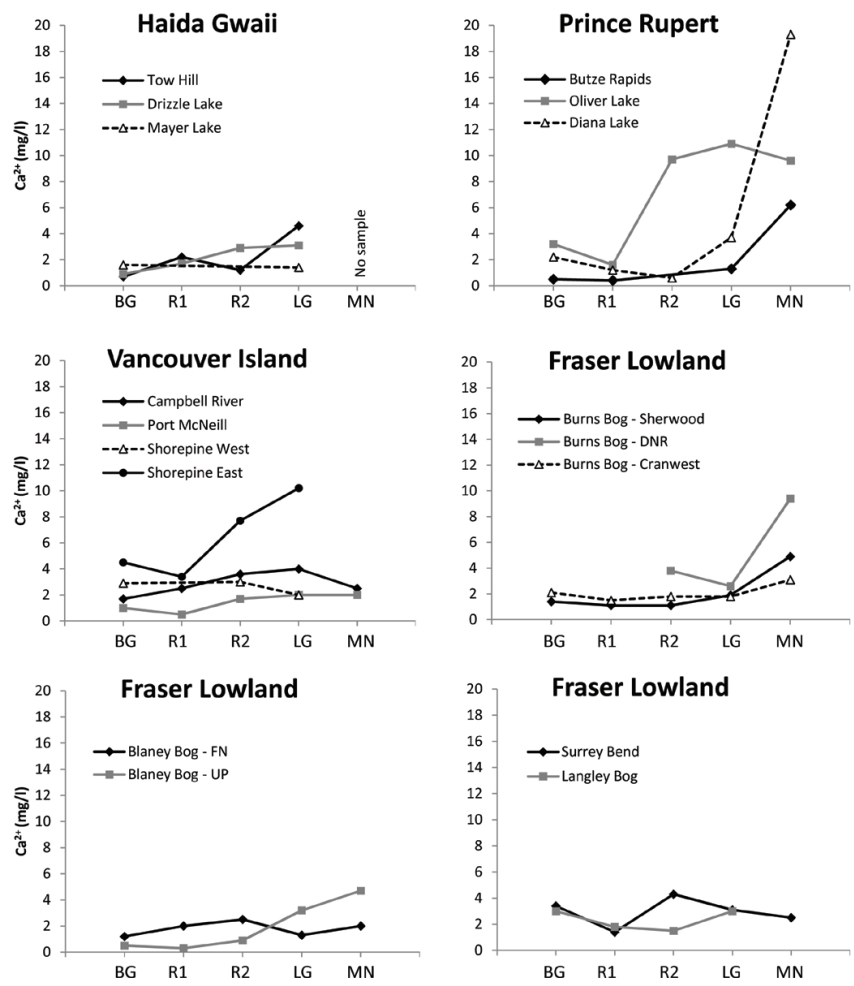

Fig. 7. Variation in calcium concentrations across the study transects.

the open bog expanse. Richardson et al. (2010) found a clear increase in $\mathrm{pH}$ at the topographic locations of the laggs derived using lidar data for four lagg transects in Ontario and Minnesota. While $\mathrm{EC}_{\text {corr }}, \mathrm{pH}$ and $\mathrm{Ca}^{2+}$ concentration may be useful indicators of the change from an ombrotrophic to minerotrophic environment for some bogs, the results of this study show that the hydrochemical transition from the bog to the lagg was neither sharp nor consistent in the coastal BC bogs studied here.

The water samples from the studied sites appear to group into two clusters: (1) $\mathrm{pH}<4.8, \mathrm{Ca}^{2+}<5 \mathrm{mg} \mathrm{L}^{-1}$, and (2) $\mathrm{pH}>5.0, \mathrm{Ca}^{2+}>2.5 \mathrm{mg} \mathrm{L}^{-1}$ (Fig. 9). Other researchers have reported bog $\mathrm{pH}$ as less than 4.5-5.0 and fen $\mathrm{pH}$ as higher than 5.5-6.0 (Wheeler and Proctor, 2000; Bourbonniere, 2009). "Cluster 1 " is representative of typical bog chemistry, whereas "cluster 2" is representative of fen or minerotrophic water (MacKenzie and Moran, 2004; Bourbonniere, 2009). All of the water samples from the BG and $\mathrm{R} 1$ sites belong to cluster 1 , whereas the remainder of the transect points were split between cluster 1 and cluster 2: $71 \%$ of R2 samples, $53 \%$ of LG samples and $27 \%$ of MN samples are part of cluster 1 . Due to the proximity of LG sites to adjacent and underlying minerotrophic soils, one would expect most of the LG sites to fall within cluster 2, but in fact, about half of the LG sites fell within cluster 1. One would expect that the cluster 1 LG sites were more affected by bog water than cluster 2 LG sites. However, the topographic evidence for this hypothesis is not very strong; 4 out of 10
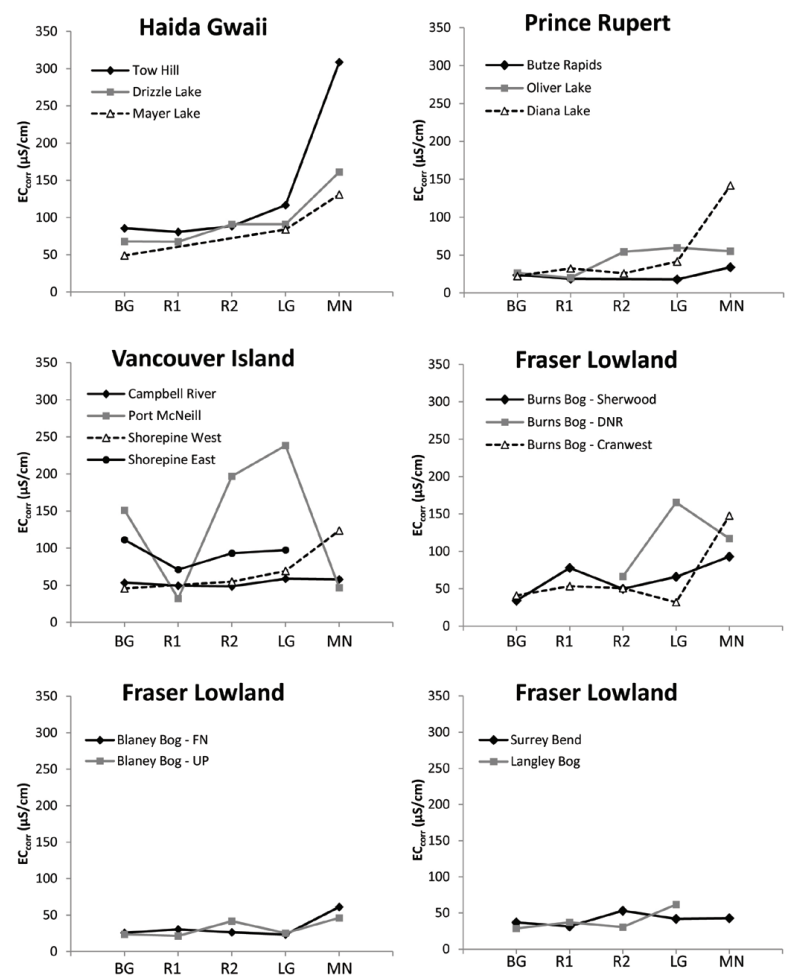

Fig. 8. Variation in $\mathrm{pH}$-corrected electrical conductivity $\left(\mathrm{EC}_{\mathrm{corr}}\right)$ across the study transects.

cluster 1 laggs, and 5 out of 9 cluster 2 laggs, were lower in elevation than the adjacent bog sites, and thus could not receive much surface runoff from the bog. The water table elevation at 8 out of the 10 LG sites in cluster 1 was lower than at the BG sites on the same transect, suggesting subsurface flow towards the lagg, but this was also the case for 4 out of the 9 LG sites in cluster 2. Subsurface flow towards the lagg may have occurred in the other bogs at other times as well (e.g. in winter, when the water table is higher). The depth to water table was significantly higher in the confined laggs compared to the unconfined laggs, but the clustering is not related to whether an LG site was confined or unconfined. Another reason for the high number of LG sites in cluster 1 could be that the peat was deeper in the cluster 1 LG sites, but the peat depth data from the LG sites do not support this hypothesis either. A final explanation is that the LG peat in cluster 2 was more influenced by minerotrophic soil than cluster 1 , regardless of topography or peat depth. Mean ash content of cluster 1 LG peat was only $20 \%$ of the mean ash content of cluster $2 \mathrm{LG}$ peat at $10 \mathrm{~cm}$ depth (4.4 vs. $21.9 \%$ ), and $70 \%$ of the mean ash content of cluster $2 \mathrm{LG}$ peat at $50 \mathrm{~cm}$ depth (20.7 vs. $29.5 \%)$. Thus, it appears that ash content of the lagg peat may have a stronger influence on the chemical composition of pore water during the early summer months than topographic position or peat depth in the lagg. Ash content therefore appears to be a useful indicator of the change from ombrotrophic to minerotrophic conditions. 


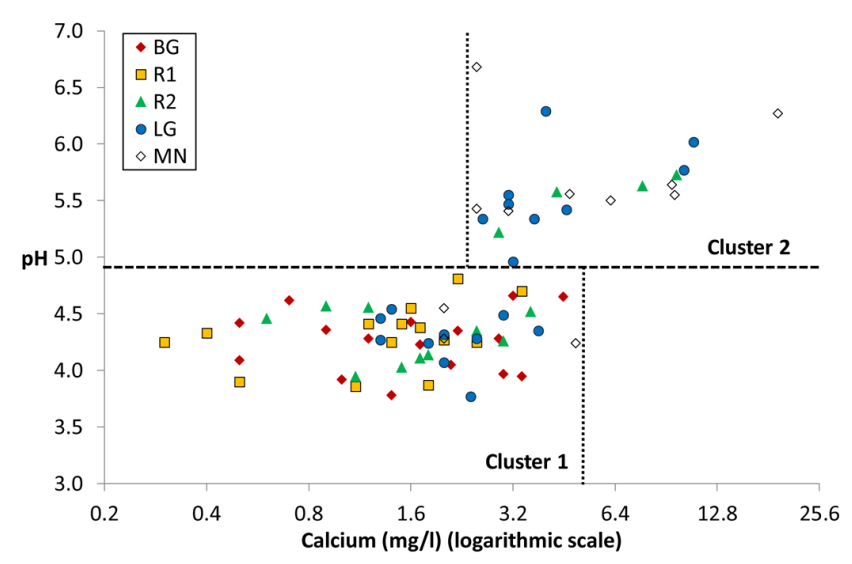

Fig. 9. Relation between $\mathrm{pH}$ and $\mathrm{Ca}^{2+}$ concentration (log scale in order to clearly show the low concentrations) for BG, R1, R2, LG and $\mathrm{MN}$ sites. Cluster 1 is representative of ombrotrophic bog conditions; cluster 2 is more similar to minerotrophic (e.g. fen) conditions (Wheeler and Proctor, 2000; MacKenzie and Moran, 2004; Bourbonniere, 2009).

A Ca: $\mathrm{Mg}$ ratio greater than $1-2$ has been proposed as a possible indicator of the mineral soil water limit (Waughman, 1980; Naucke et al., 1993; Bragazza and Gerdol, 1999). For example, Bragazza et al. (2005) found a sharp increase in the $\mathrm{Ca}: \mathrm{Mg}$ ratio from the bog expanse to the minerotrophic margin of an Italian and a Swedish bog. In this study, the $\mathrm{Ca}: \mathrm{Mg}$ ratio did not consistently indicate the mineral soil water limit; only 8 out of the 17 transects (47\%) showed an increase in the $\mathrm{Ca}: \mathrm{Mg}$ ratio from bog to forest. None of the correlations between the $\mathrm{Ca}: \mathrm{Mg}$ ratio and position on the transect were statistically significant.

\subsubsection{Regional variation}

For the BG sites, $\mathrm{pH}$ of near-surface pore water decreased significantly with increasing peat depth (Fig. 10); $\mathrm{pH}$ also increased with latitude and mean annual precipitation, but these trends were not significant ( $p=0.064$ and 0.066 , respectively). Acidity was also significantly correlated with peat depth and latitude, due to its correlation with $\mathrm{pH}(\mathrm{Ta}-$ ble 3). Riley (2011) found a similar relation between $\mathrm{pH}$ and latitude for bogs of the Hudson Bay Lowlands, and noted that $\mathrm{pH}$ was above 4.0 in bogs with peat depths less than $1.5 \mathrm{~m}$. Riley (2011) attributed the geographic variation in $\mathrm{pH}$ to isostatic rebound over the past $5500 \mathrm{yr}$, whereby the land that emerged first has the deepest peat and the lowest $\mathrm{pH}$. Shallower bogs are thought to have a higher $\mathrm{pH}$ due to a greater contribution of water from the mineral substrate (Riley, 2011). Similarly, in our study, the Fraser Lowland bogs with the greatest peat depths had the lowest $\mathrm{pH}$ (Fig. 10).

For the eight transects in the Pacific Oceanic wetland region (north and south coast subregions), $\mathrm{pH}$ in the $\mathrm{BG}$ sites was above 4.2; for the nine transects in the Pacific Temperate

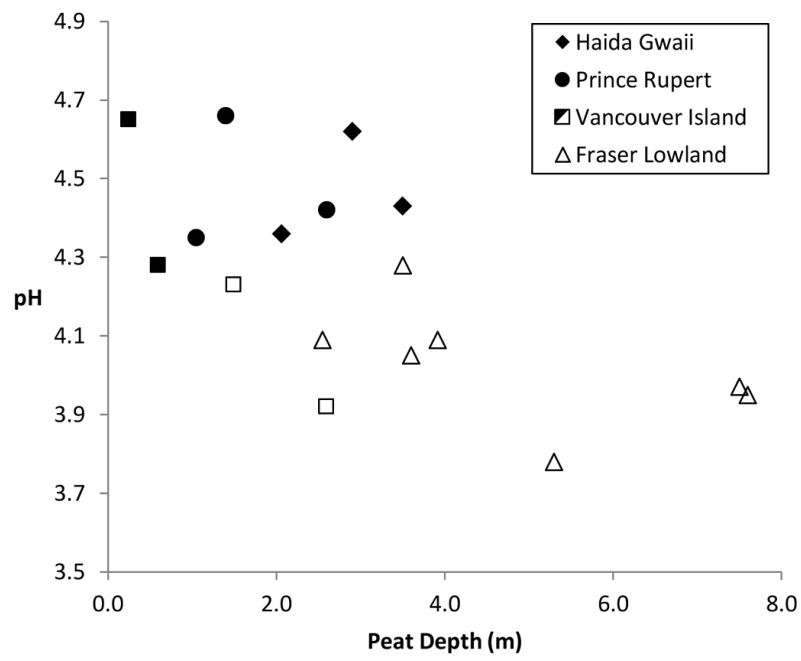

Fig. 10. Relation between $\mathrm{pH}$ and peat depth for the BG sites (Pearson linear correlation: $r^{2}=0.42, p=0.005$; Spearman rank correlation: $\left.r_{\mathrm{S}}=-0.61, p=0.009\right)$. Legend shows the four study regions in coastal British Columbia. Solid symbols represent bogs in the Pacific Oceanic wetland region; open symbols represent bogs in the Pacific Temperate wetland region.

wetland region, $\mathrm{pH}$ was below 4.3 (Fig. 10). The difference in mean $\mathrm{pH}$ in the $\mathrm{BG}$ sites between the Pacific Oceanic and Pacific Temperate wetland regions is statistically significant. This difference may be explained by the differences in peat depth, as described above. Another possible explanation is the difference in mean annual rainfall between the two wetland regions (average of $2117 \mathrm{~mm} \mathrm{yr}^{-1}$ for the Pacific Oceanic region and $1044 \mathrm{~mm} \mathrm{yr}^{-1}$ for the Pacific Temperate region, NWWG, 1988). In July and August, the studied Pacific Oceanic bogs receive, on average, $\sim 60 \%$ more rainfall than the studied Pacific Temperate bogs (Table 1). The studied bogs in the Pacific Oceanic wetland region received, on average, $76 \mathrm{~mm}$ (standard deviation: $19 \mathrm{~mm}$ ) of rainfall in the month preceding sampling; the studied bogs in the Pacific Temperate wetland region received $65 \mathrm{~mm}$ (standard deviation: $17 \mathrm{~mm}$ ) in the month prior to sampling. Higher rainfall in the Pacific Oceanic wetland region may dilute near-surface pore water so that it is less acidic and more similar to rainwater. The drier and warmer conditions of the Pacific Temperate wetland region would result in greater evapotranspiration and concentration of bog water, thereby lowering the $\mathrm{pH}$ of near-surface pore water. Measurements were taken on different dates and under a variety of weather conditions, leading to some variability due to the time of sampling. However, $\mathrm{pH}$ of near-surface pore water tends to have a high temporal stability in bogs, and measurements were taken in MayJuly when the concentration effect due to evapotranspiration is not as pronounced as later in summer (Howie, 2013; Vitt et al., 1995; Wieder, 1985). Howie (2013) showed for two bogs in the Fraser Lowland that $\mathrm{pH}$ measured in June was within 0.25 of the mean $\mathrm{pH}$ in a $1.5 \mathrm{yr}$ study. 
$\mathrm{EC}_{\text {corr }}$ was generally higher in the Haida Gwaii and Vancouver Island bogs than the Prince Rupert and Fraser Lowland bogs. $\mathrm{Na}^{+}$and $\mathrm{Mg}^{2+}$ concentrations were lowest in the Prince Rupert bogs and highest in the Haida Gwaii bogs (Fig. 11). Since bogs in the Prince Rupert area receive approximately $1000 \mathrm{~mm}$ more precipitation annually than those in Haida Gwaii, the low ionic concentrations could be a result of the high rainfall, but it may also be caused by differences in precipitation chemistry. Vitt et al. (1990) studied bogs on Haida Gwaii (Graham Island) and in the Prince Rupert area, and similarly found that $\mathrm{Na}^{+}$and $\mathrm{Cl}^{-}$(and, to a lesser extent, $\mathrm{Mg}^{2+}$ ) concentrations were much higher for bogs on Haida Gwaii than bogs in the Prince Rupert area and islands to the south of Prince Rupert. They attributed this variation to a coastal-inland gradient of decreasing concentrations of cations and anions, particularly $\mathrm{Na}^{+}$and $\mathrm{Cl}^{-}$, with distance from the coast. Malmer et al. (1992) reported a similar gradient in surface water chemistry of peatlands across western Canada. He found that $\mathrm{Na}^{+}, \mathrm{Mg}^{2+}$ and $\mathrm{Cl}^{-}$concentrations were approximately 9,8 and 7 times higher, respectively, in Haida Gwaii bogs than in Prince Rupert bogs. In the BG sites of our study, average $\mathrm{Na}^{+}$and $\mathrm{Mg}^{2+}$ concentrations were 5 and 3 times higher, respectively, in Haida Gwaii bogs than in Prince Rupert bogs. It is well established that the ionic concentrations in surface water of ombrotrophic bogs reflect local precipitation (Gorham, 1955; Proctor, 1995), so the clear difference in ion concentrations between the Haida Gwaii and Prince Rupert bogs can probably be attributed to higher ion concentrations in precipitation and increased dry deposition at the exposed, hyperoceanic bogs on Haida Gwaii, compared to the more sheltered bogs on the mainland near Prince Rupert. For example, mean annual precipitation chemistry data from 1978 to 1985 showed that $\mathrm{Na}^{+}, \mathrm{Mg}^{2+}$ and $\mathrm{Cl}^{-}$ concentrations were all 2.3 times higher in Port Hardy (exposed to open ocean) than at Vancouver International Airport (sheltered by Vancouver Island) (National Atmospheric Chemistry Database, 2012). Munger and Eisenreich (1983) compiled several precipitation chemistry datasets for North America and noted that $\mathrm{Ca}^{2+}$ concentrations were lowest in the Prince Rupert area and increased towards the southeast; $\mathrm{Mg}^{2+}$ concentrations followed a similar pattern and were correlated with $\mathrm{Ca}^{2+}$ concentrations $(r=0.83)$.

The $\mathrm{Ca}: \mathrm{Mg}$ ratio for the $\mathrm{BG}$ sites ranged from 0.4 to 10.0 , and showed a distinct regional pattern: the $\mathrm{Ca}: \mathrm{Mg}$ ratio was lowest in the Haida Gwaii bogs (mean: 1.0) and highest in the Prince Rupert bogs (mean: 5.3). This pattern was mainly influenced by the $\mathrm{Mg}^{2+}$ concentrations; $\mathrm{Ca}^{2+}$ concentrations did not display a similar regional pattern. Of the BG sites, $82 \%$ and $59 \%$ had a $\mathrm{Ca}: \mathrm{Mg}$ ratio greater than 1 and 2 , respectively, which is often taken as the mineral soil water limit. The $\mathrm{Ca}: \mathrm{Mg}$ ratio in the BG sites of the Fraser Lowland (mean: 4.6) and Vancouver Island bogs (mean: 2.7) as well as Prince Rupert were all higher than 2, so a $\mathrm{Ca}: \mathrm{Mg}$ of 1 or 2 as an indicator of the mineral soil water limit is clearly too low for the coastal BC region. Due to the variable
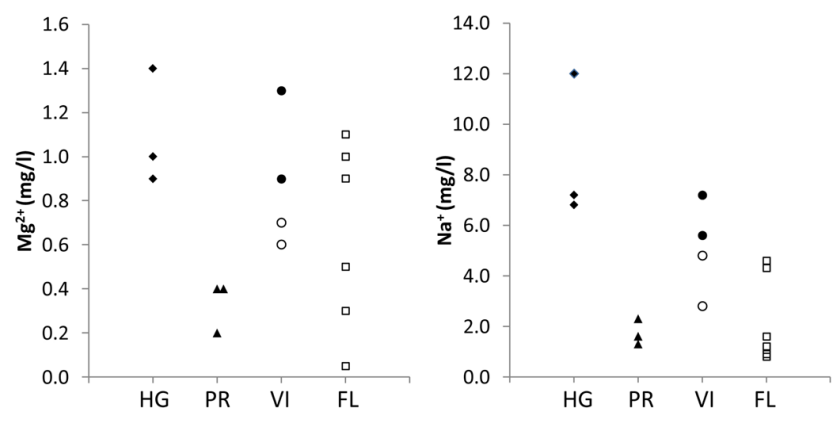

Fig. 11. Magnesium and sodium concentrations for BG sites in the four study regions: Haida Gwaii (HG), Prince Rupert (PR), Vancouver Island (VI) and Fraser Lowland (FL). Solid symbols represent bogs in the Pacific Oceanic wetland region; open symbols represent bogs in the Pacific Temperate wetland region.

oceanic influence, the $\mathrm{Ca}: \mathrm{Mg}$ ratio would vary for each location based on local precipitation chemistry. The average $\mathrm{Ca}: \mathrm{Mg}$ ratio in precipitation between 1978 and 1985 was 1.0 at Port Hardy and 5.4 at Vancouver International Airport (National Atmospheric Chemistry Database, 2012), indicating regional patterns in precipitation chemistry.

\section{Conclusions}

Clear hydrological and hydrochemical gradients were identified across the bog expanse-bog margin transition for 13 coastal $\mathrm{BC}$ bogs, with increasing depth to water table, $\mathrm{pH}$, $\mathrm{Ca}^{2+}$ concentrations and $\mathrm{pH}$-corrected electrical conductivity from the bog to the lagg. However, these gradients were not consistent or significant for all bogs, and the hydrochemical parameters do not appear to be as useful for locating the mineral soil water limit at the bog margin as suggested in previous studies. The mineral content of peat samples usually increased across the bog expanse-bog margin transition; ash content in near-surface peat (10 and $50 \mathrm{~cm}$ depth) appears to be the most useful abiotic measure for determining the location of the lagg.

Regional variability in bog hydrochemistry was related to the wetland regions defined by NWWG (1988), latitude, annual precipitation and oceanic influence. Specifically, $\mathrm{pH}$ increased with latitude and mean annual precipitation, and decreased with increasing peat depth. $\mathrm{Na}^{+}$and $\mathrm{Mg}^{2+}$ concentrations, and $\mathrm{EC}_{\mathrm{corr}}$, were highest in the Haida Gwaii bogs and lowest in the Prince Rupert bogs, which suggests a coastal-inland gradient of decreasing cation and anion concentrations. Despite the apparent similarities in climate and vegetation throughout coastal $\mathrm{BC}$, bogs differ significantly from one another in terms of peat depth and hydrochemistry.

While the values and patterns are specific for this set of coastal bogs, the observed patterns in depth to water table, near-surface hydrochemistry and peat properties (especially ash content), as well as the observation that there are large 
variations in lagg characteristics locally and regionally, expand our currently limited knowledge of the role of the lagg in raised bog development and functioning. These local and regional gradients must be taken into consideration when comparing different bogs and laggs, especially when contemplating the use of data from one bog as a reference ecosystem for the restoration of another bog in the same region.

Acknowledgements. Metro Vancouver Regional Parks (West Area) gave permission for research in the Burns Bog Ecological Conservancy Area (BBECA), Metro Vancouver Regional Parks (East Area) for research in Blaney Bog and The Corporation of Delta for research in the Delta Nature Reserve and a Delta-owned property outside the BBECA. Thanks to Warren Nottingham for allowing access to the Sherwood Forest lagg, and to Norm Spencer for allowing entry through the Cranwest Farms property to access the lagg south of the farm. Funding for and analysis of the water samples was provided by Environment Canada. Funding for travel was provided by Metro Vancouver Regional Parks. Additional funding for S.A.H. was provided by Simon Fraser University. Field equipment for this research was provided by Simon Fraser University, The Corporation of Delta and Metro Vancouver Regional Parks. Field assistance from W. Howie, S. Howie, K. Howie, J. Hughes, T. Andrade, A. Robinson, E. Baird, C. Baird, A. Danyluk, E. Riddell, K. Houghton, A. Graham, J. Niu, A. Snow, N. Murphy, B. Jones, S. Zimmerman, Delta surveyors, Delta co-op students and Metro Vancouver park operators is greatly appreciated.

Edited by: A. D. Reeves

\section{References}

Baird, A. J., Eades, P. A., and Surridge, B. W. J.: The hydraulic structure of a raised bog and its implications for ecohydrological modeling of bog development, Ecohydrology, 1, 289-298, 2008.

Baird, E.: Ecohydrological overview of Surrey Bend Regional Park during summer conditions, Report by Simon Fraser University, Burnaby, BC, 2011.

Blackwell, I.: A Hydrological study of the lagg zone of Clara Bog, County Offaly, Ireland, Masters thesis, Imperial College, University of London, 1992.

Bourbonniere, R. A.: Review of water chemistry research in natural and disturbed peatlands, Can. Water Resour. J., 34, 393-414, 2009.

Bragazza, L. and Gerdol, R.: Hydrology, groundwater chemistry and peat chemistry in relation to habitat conditions in a mire on the South-eastern Alps of Italy, Plant Ecol., 144, 243-256, 1999.

Bragazza, L. and Gerdol, R.: Are nutrient availability and acidityalkalinity gradients related in Sphagnum-dominated peatlands?, J. Veg. Sci., 13, 473-482, 2002.

Bragazza, L., Rydin, H., and Gerdol, R.: Multiple gradients in mire vegetation: a comparison of a Swedish and an Italian bog, Plant Ecol., 177, 223-236, 2005.

Bridgham, S. D., Pastor, J., Janssens, J. A., Chapin, C., and Malterer, T.: Multiple limiting gradients in peatlands: a call for a new paradigm, Wetlands, 16, 45-65, 1996.

Bubier, J. L.: Patterns of Picea mariana (Black Spruce) growth and raised bog development in Victory Basin, Vermont, Bulletin of the Torrey Botanical Club, 118, 399-411, 1991.
Clague, J. J.: Quaternary geology of the Queen Charlotte Islands, in: The Outer Shores: based on the proceedings of the Queen Charlotte Islands First International Scientific Symposium, edited by: Scudder, G. E. and Gessler, N., University of British Columbia, August 1984, 1989.

Clague, J. J., Luternauer, J. L., Pullan, S. E., and Hunter, J. A.: Postglacial deltaic sediments, southern Fraser River delta, British Columbia, Canadian J. Earth Sci., 28, 1386-1393, 1991.

Clymo, R. S.: The limits to peat bog growth, Philos. T. R. Soc. B, 303, 605-654, 1984.

Damman, A. W. H.: Geographical patterns in peatland development in eastern North America, in: Proceedings of the International Symposium on Classification of Peat and Peatlands, edited by: Kivenin, E., Heikurainen, L., and Pakarinen, P., International Peat Society, 42-57, 1979.

Damman, A. W. H.: Hydrology, development, and biogeochemistry of ombrogenous peat bogs with special reference to nutrient relocation in a western Newfoundland bog, Can. J. Botany, 64, 384394, 1986.

Damman, A. W. H. and French, T. W.: The ecology of peat bogs of the glaciated northwestern United States: a community profile, US Fish and Wildlife Service Biological Report 85, 1987.

de Vleeschouwer, F., Chambers, F. M. and Swindles, G. T.: Coring and sub-sampling of peatlands for paleoenvironmental research, Mires and Peat, 7, 1-10, 2010.

Devito, K. J., Waddington, J. M., and Branfireun, B. A.: Flow reversals in peatlands influenced by local groundwater systems, Hydrol. Process., 11, 103-110, 1997.

Egglesmann, R., Heathwaite, A. L., Grosse-Brauckmann, G., Kuster, E., Naucke, W., Schuch, M., and Schweickle, V.: Physical processes and properties of mires, in: Mires: Process, Exploitation and Conservation, edited by: Heathwaite, A. L. and Gottlich, Kh., John Wiley \& Sons Ltd., Chichester, 171-262, 1993.

Environment Canada (National Climate Data and Information Archive): available at: http://www.climate.weatheroffice.gc.ca/ climateData/canada_e.html (last access: 3 November 2012), 2012.

Glaser, P. H.: Vegetation and water chemistry, in: The patterned peatlands of Minnesota, edited by: Wright Jr., H. E., Coffin, B. A., and Asseng, N. E. P., Univ. Minnesota Press, St. Paul, 15-26, 1992.

Glaser, P. H., Janssens, J. A., and Siegel, D. I.: The response of vegetation to chemical and hydrological gradients in the Lost River peatland, northern Minnesota, J. Ecol., 78, 1021-1048, 1990.

Glaser, P. H., Siegel, D. I., Romanowicz, E. A., and Shen, Y. P.: Regional linkages between raised bogs and the climate, groundwater, and landscape of north-western Minnesota, J. Ecol., 85, 3-16, 1997.

Golinski, G. K.: Mires of Vancouver Island, British Columbia: vegetation classification and differences between disturbed and undisturbed mires, Ph.D. thesis, University of Victoria, Victoria, BC, 2004.

Gorham, E.: Variation in some chemical conditions along the borders of a Carex lasiocarpa fen community, Oikos, 2, 217-240, 1950.

Gorham, E.: On some factors affecting the chemical composition of Swedish fresh waters, Geochim. Cosmochim. Ac., 7, 129-150, 1955. 
Hebda, R. J.: The paleoecology of a raised bog and associated deltaic sediments of the Fraser River delta, Ph.D. thesis, University of British Columbia, Vancouver, BC, 1977.

Hebda, R. J.: Late-glacial and post glacial vegetation history at Bear Cove Bog, northeast Vancouver Island, British Columbia, Can. J. Botany, 61, 3172-3192, 1983.

Hobbs, N. B.: Mire morphology and the properties and behaviour of some British and foreign peats, Q. J. Eng. Geol., 19, 7-80, 1986.

Howie, S. A.: Bogs and their laggs in coastal British Columbia: characteristics of topography, depth to water table, hydrochemistry, peat properties, and vegetation at the bog margin, $\mathrm{PhD}$ thesis, Simon Fraser University, Burnaby, BC, 2013.

Howie, S. A. and Tromp-van Meerveld, I.: The essential role of the lagg in raised bog function and restoration: a review, Wetlands, 31, 613-622, 2011.

Howie, S. A. and van Meerveld, H. J.: Temporal variation in depth to water table and hydrochemistry in three raised bogs and their laggs in coastal British Columbia, Canada, Hydrol. Earth Syst. Sci. Discuss., 9, 14065-14107, doi:10.5194/hessd9-14065-2012, 2012.

Howie, S. A., Whitfield, P. H., Hebda, R. J., Dakin, R. A., and Jeglum, J. K.: Can analysis of historic lagg forms be of use in the restoration of highly altered raised bogs? Examples from Burns Bog, British Columbia, Can. Water Resour. J., 34, 427440, 2009a.

Howie, S. A., Whitfield, P. H., Hebda, R. J., Munson, T. G., Dakin, R. A., and Jeglum, J. K.: Water table and vegetation response to ditch blocking: restoration of a raised bog in southwestern British Columbia, Can. Water Resour. J., 34, 381-392, 2009 b.

Hulme, P. D.: The classification of Scottish peatlands, Scot. Geogr. Mag., 96, 46-50, 1980.

Ingram, H. A. P.: Hydrology, in: Ecosystems of the world. 4B. Mires, swamp, bog, fen and moor, edited by: Gore, A. J. P., Regional studies, Elsevier, Oxford, 67-158, 1983.

Ivanov, K. E.: Water Movement in Mirelands, Academic Press, London, 1981.

Lähteenoja, O., Ruokolainen, K., Schulman, L., and Alvarez J.: Amazonian floodplains harbour minerotrophic and ombrotrophic peatlands, Catena, 79, 140-145, 2009.

Mackenzie, W. H. and Moran, J. R.: Wetlands of British Columbia. Land Management Handbook 52, B.C. Ministry of Forests, Victoria, British Columbia, 2004.

Malmer, N., Horton, D. G., and Vitt, D. H.: Element concentrations in mosses and surface waters of western Canadian mires relative to precipitation chemistry and hydrology, Ecography, 15, 114128, 1992.

Mathewes, R. W. and Clague, J. J.: Stratigraphic relationships and paleoecology of a late-glacial peat bed from the Queen Charlotte Islands, British Columbia, Can. J. Earth Sci., 19, 1185-1195, 1982.

Mitchell, C. P. J., Branfireun, B. A., and Kolka, R. K.: Spatial characteristics of net methylmercury production hotspots in peatlands, Environ. Sci. Technol., 42, 1010-1016, 2008.

Moore, P. D. and Bellamy, D. J.: Peatlands, Springer-verlag, New York, 1974.

Munger, J. W. and Eisenreich, S. J.: Continental-scale variations in precipitation chemistry, Environ. Sci. Technol., 17, 32A-42A, 1983.
National Atmospheric Chemistry Database: available at: http:// www.ec.gc.ca/natchem (last access: 12 October 2012), 2012.

National Wetlands Working Group (NWWG): Wetlands of Canada, Environment Canada, Ecological Land Classification Series, No. 24, 1988.

Naucke, W., Heathwaite, A. L., Egglesmann, R., and Schuch, M.: Mire chemistry, in: Mires: Process, Exploitation and Conservation, edited by: Heathwaite, A. L. and Göttlich, Kh., John Wiley \& Sons Ltd., Chichester, 263-310, 1993.

Proctor, M. C.: The ombrogenous bog environment, in: Restoration of Temperate Wetlands, edited by: Wheeler, B. D., Shaw, S. C., Fojt, W. J., and Robertson, R. A., John Wiley \& Sons Ltd., Chichester, 287-304, 1995.

Richardson, M. C., Mitchell, C. P. J., Branfireun, B. A., and Kolka, R. K.: Analysis of airborne LiDAR surveys to quantify the characteristic morphologies of northern forested wetlands, J. Geophys. Res., 115, G03005, doi:10.1029/2009JG000972, 2010.

Riley, J. L.: Wetlands of the Hudson Bay Lowland: an Ontario overview, Nature Conservancy of Canada, Toronto, ON, 2011.

Rydin, H. and Jeglum, J. K.: The biology of peatlands, Oxford University Press, UK, 2006.

Schouten, M. G. C. (Ed.): Conservation and restoration of raised bogs: geological, hydrological and ecological studies, Department of Environment and Local Government, Dublin, 2002.

Sherwood, J. H., Kettridge, N., Thompson, D. K., Morris, P. J., Silins, U., and Waddington, J. M.: Effect of drainage and wildfire on peat hydrophysical properties, Hydrol. Process., 27, 18661874, 2013.

Shotyk, W.: Peat bog archives of atmospheric metal deposition: geochemical evaluation of peat profiles, natural variations in metal concentrations, and metal enrichment factors, Environ. Rev., 4, 149-183, 1996.

Sjörs, H.: On the relation between vegetation and electrolytes in north Swedish mire waters, Oikos, 2, 241-258, 1950.

Sjörs, H. and Gunnarsson, U.: Calcium and $\mathrm{pH}$ in north and central Swedish mire waters, J. Ecol., 90, 650-657, 2002.

Stoneman, R. and Brooks, S. (Eds.): Conserving Bogs: The Management Handbook, The Stationary Office, Edinburgh, 1997.

Tahvanainen, T., Sallantaus, T., Heikkila, R., and Tolonen, K.: Spatial variation of mire surface water chemistry and vegetation in northeastern Finland, Ann. Bot. Fennici, 39, 235-251, 2002.

Vitt, D. H., Horton, D. G., Slack, N. G., and Malmer, N.: Sphagnumdominated peatlands of the hyperoceanic British Columbia coast: patterns in surface water chemistry and vegetation, Can. J. Forest Res., 20, 696-711, 1990.

Vitt, D. H., Bayley, S. E., and Jin, T.: Seasonal variation in water chemistry over a bog-rich fen gradient in Continental Western Canada, Can. J. Fish. Aquat. Sci., 52, 587-606, 1995.

Wassen, M. J. and Joosten, J. H. J.: In search of a hydrological explanation for vegetation changes along a fen gradient Biebrza Upper Basin (Poland), Vegetatio, 124, 191-209, 1996.

Waughman, G. J.: Chemical aspects of the ecology of some south German peatlands, J. Ecol., 68, 1025-1046, 1980.

Wheeler, B. D. and Proctor, M. C. F.: Ecological gradients, subdivisions and terminology of north-west European mires, J. Ecol., 88, 187-203, 2000.

Wieder, R. K.: Peat and water chemistry at Big Run Bog, a peatland in the Appalachian mountains of West Virginia, USA, Biogeochemistry, 1, 277-302, 1985. 